\title{
Rapid emplacement of the Central Atlantic Magmatic Province as a net sink for $\mathrm{CO}_{2}$
}

\author{
Morgan F. Schaller ${ }^{\text {a,* }}$, James D. Wright ${ }^{\text {a }}$, Dennis V. Kent ${ }^{\mathrm{a}, \mathrm{b}}$, Paul E. Olsen ${ }^{\mathrm{b}}$ \\ a Earth and Planetary Sciences, Rutgers University, 610 Taylor Rd. Piscataway, NJ 08854, USA \\ b Lamont-Doherty Earth Observatory of Columbia University, Rt. 9W, Palisades, NY 10964, USA
}

\section{A R T I C L E I N F O}

\section{Article history:}

Received 8 June 2011

Received in revised form 21 October 2011

Accepted 21 December 2011

Available online $\mathrm{xxxx}$

Editor: G. Henderson

\section{Keywords:}

Large Igneous Province

atmospheric carbon dioxide

Triassic-Jurassic

$\mathrm{CO}_{2}$ chemical weathering

\begin{abstract}
A B S T R A C T
Recent evidence from the 201.5 Ma Central Atlantic Magmatic Province (CAMP) in the Newark rift basin demonstrates that this Large Igneous Province produced a transient doubling of atmospheric $\mathrm{pCO}_{2}$, followed by a falloff to pre-eruptive concentrations over $300 \mathrm{kyr}$. This paper confirms the short-term findings from the Newark basin, and tests the million-year effects of the CAMP volcanism on Early Jurassic $\mathrm{pCO}_{2}$ from strata in the corollary Hartford basin of Eastern North America (ENA) also using the pedogenic carbonate paleobarometer. We find $\mathrm{pCO}_{2}$ levels for pre-CAMP background of $2000 \pm 700 \mathrm{ppm}$ (at $S(z)=3000 \pm 1000 \mathrm{ppm}$ ), increasing to $5000 \pm 1700 \mathrm{ppm}$ immediately above the first lava flow unit, consistent with observations from the Newark. The longer post-extrusive Portland Formation of the Hartford basin records a fourth pulse of $\mathrm{pCO}_{2}$ to $4500 \pm 1200 \mathrm{ppm}$, about $240 \mathrm{kyr}$ after the last lava recorded in the ENA section. We interpret this fourth increase as due to a major episode of volcanism, and revise the main CAMP duration to $840 \pm 60 \mathrm{kyr}$. The Portland also records a post-eruptive decrease in $\mathrm{pCO}_{2}$ reaching pre-eruptive background concentrations of $\sim 2000 \mathrm{ppm}$ in only $\sim 300 \mathrm{kyr}$, and continuing to levels below pre-CAMP background over the subsequent 1.5 Myr following the final episode of eruptions. Geochemical modeling (using modified COPSE code) demonstrates that the rapidity of the $\mathrm{pCO}_{2}$ decreases, and fall to concentrations below background can be accounted for by a 1.5-fold amplification of the continental silicate weathering response due to the presence of the CAMP basalts themselves. These results demonstrate that a continental flood basalt capable of producing a short-term perturbation of the carbon system may actually have an overall netcooling effect on global climates due to a long-term net-decrease in $\mathrm{pCO}_{2}$ to below pre-eruptive levels, as previous models have suggested followed the emplacement of the Deccan Traps.
\end{abstract}

(c) 2012 Elsevier B.V. All rights reserved.

\section{Introduction}

Covering millions of square kilometers of continental area, continental flood basalts are Large Igneous Provinces (LIPs) that may produce in excess of several million cubic kilometers of lava (Coffin and Eldholm, 1993). The great volume and aerial extent of these eruptions, and their intriguing association with mass extinction events throughout earth history (Courtillot and Renne, 2003; Wignall, 2001), has spurred interest in the potential of LIPs to alter the composition of Earth's atmosphere through the emission of gases - primarily $\mathrm{SO}_{2}$ and $\mathrm{CO}_{2}$ (Self et al., 2008). Until recently, geochemical modeling and effusive flux estimates seemed to suggest that $\mathrm{CO}_{2}$ degassed during continental flood volcanism probably has a negligible long-term effect on the atmosphere (e.g., Caldeira and Rampino, 1990; Self et al., 2006). Most recently, Schaller et al. (2011a) tested the direct effects of a LIP using the pedogenic carbonate paleobarometer (Cerling, 1999) on sediments in superposition with the extrusives of the Triassic-Jurassic Central Atlantic Magmatic Province (CAMP) in the Newark basin of eastern North America (Fig. 1).

\footnotetext{
* Corresponding author.

E-mail address: schaller@rci.rutgers.edu (M.F. Schaller).
}

Schaller et al. (2011a) demonstrated that the short term $\left(10^{4}-10^{5}\right.$ year) effects of a continental flood basalt on atmospheric $\mathrm{pCO}_{2}$ may be substantial - a doubling of $\mathrm{pCO}_{2}$ in apparent response to each magmatic episode - and yet quite transient with a steady decrease in atmospheric $\mathrm{pCO}_{2}$ over the $\sim 300 \mathrm{kyr}$ following each volcanic episode.

Several independent geochemical models have predicted such a transient response following the eruption of the Deccan Traps (Caldeira and Rampino, 1990; Dessert et al., 2001). The model of Dessert et al. (2001) specifically predicts atmospheric $\mathrm{CO}_{2}$ concentrations falling some $20 \%$ below pre-eruptive background by about 1 million years after the eruption of the Deccan Traps, an effect attributed to an acceleration of global silicate weathering further amplified by the presence of fresh weatherable basalt. However, due to the absence of continuous sedimentary sections where the appropriate lithology is interbedded with volcanics, such a response to any LIP other than the CAMP has not yet been explicitly identified. Encouragingly, immediately post-eruptive $\mathrm{pCO}_{2}$ decreases have been observed in the Newark basin following the CAMP eruptions (Schaller et al., 2011a), and the corollary Hartford basin of eastern North America contains a much longer post-extrusive section (Kent and Olsen, 2008) where the long-term response of the system may be tested. In this paper we first use the pedogenic carbonate paleobarometer (Cerling, 1999) to demonstrate increases in $\mathrm{pCO}_{2}$ coincident with 


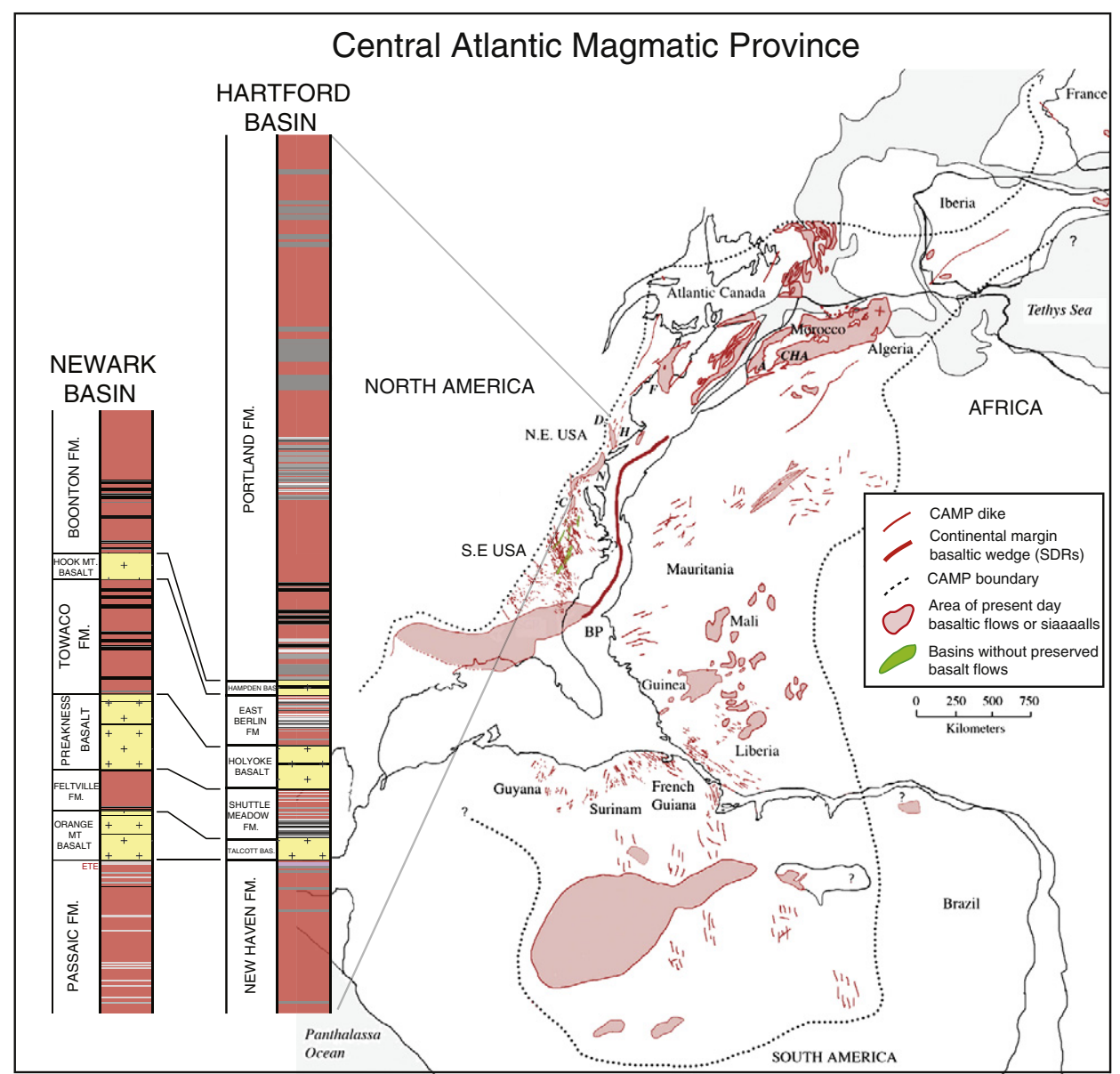

Fig. 1. The distribution of the remaining CAMP volcanics and stratigraphy of the Newark and Hartford basins of Eastern North America. Modified from Whiteside et al. (2007), which is based on McHone (2000).

pulses of CAMP volcanism in the equivalent strata of the Hartford basin. We further use the thick post-CAMP Portland Formation to evaluate the long-term decrease in $\mathrm{pCO}_{2}$ as a function of increased global silicate weathering, testing the hypothesis that the presence of $2-4 \times 10^{6} \mathrm{~km}^{3}$ of fresh CAMP basalt (McHone et al., 2003) is capable of reducing $\mathrm{pCO}_{2}$ to below pre-eruptive background concentrations.

\section{The CAMP record in the Newark and Hartford basins}

The Central Atlantic Magmatic Province (CAMP; Marzoli et al., 1999) is perhaps the largest continental flood basalt of the Phanerozoic, with latest Triassic and earliest Jurassic tholeiitic basalts and mafic intrusions preserved on four continents, and an aerial extent of greater than $1.12 \times 10^{7} \mathrm{~km}^{2}$ (McHone et al., 2003) (Fig. 1). CAMP basalts span the Mesozoic rift zone of the Pangean supercontinent, and despite heavy erosion, are well exposed in the rift basins of eastern North America and Morocco, where they have been extensively studied. More poorly understood constituents of the CAMP are preserved in West Africa, Europe, and extensive regions of South America. However, ${ }^{40} \mathrm{Ar} /{ }^{39} \mathrm{Ar}$ radiometric ages for this vast collection of lava flows and intrusives are essentially indistinguishable within the dating error (e.g., Hames et al., 2000; Jourdan et al., 2009; Knight et al., 2004; Marzoli et al., 2004; Marzoli et al., 2011; Nomade et al., 2007; Verati et al., 2007), and center the eruptive events around $\sim 201 \mathrm{Ma}$. More precise $\mathrm{U}-\mathrm{Pb}$ dates place some of the first flow units at 201.38 $\pm 0.31 \mathrm{Ma}$ (Schoene et al., 2010) in Eastern North America.

The half-graben rift basins of the Newark Supergroup in Eastern North America contain Late Triassic to Early Jurassic age strata, the majority of which are shallow to deep lacustrine, fluvial, alluvial and playa facies (Olsen, 1997; Smoot, 1991). The lacustrine sedimentary units in each basin display a rhythmic succession of facies that reflect periodic fluctuations in lake depth (Van Houten, 1962), which have been related directly to Milankovitch orbital forcing of tropical precipitation (Olsen, 1986; Olsen and Kent, 1996). The stratigraphy of the Newark basin is precisely known from a continuous cored section through the center of the basin (Kent et al., 1995; Olsen et al., 1996a), and this record of orbitally forced sedimentation provides the astronomical chronometer used to construct the geomagnetic polarity time scale for more than $33 \mathrm{Myr}$ of the Late Triassic and Early Jurassic (Kent and Olsen, 1999; Kent et al., 1995; Olsen and Kent, 1996, 1999).

The CAMP extrusive interval sits near the top of the Newark basin section and is composed of three lava flow units (stratigraphically upward, the Orange Mountain, Preakness, and Hook Mountain Basalts), with significant sedimentary sequences above each of them (Feltville, Towaco, and Boonton Formations, respectively) (Figs. 1 and 4). Milankovitch cycle-stratigraphy on these sediments has constrained the duration of volcanism in the Newark basin to $\sim 600 \pm 20 \mathrm{kyr}$ (Olsen et al., 1996b; Olsen et al., 2003; Whiteside et al., 2007), where the Feltville Formation represents $\sim 260 \mathrm{kyr}$, the Towaco Formation $\sim 290 \mathrm{kyr}$; the first flow unit (Orange Mountain Basalt) was apparently extruded within a single precession cycle. The Hook Mountain Basalt is also within a precession cycle whereas the duration of the Preakness Basalt can presently only be constrained to $\sim 60 \pm 20 \mathrm{kyr}$ (Whiteside et al., 2007). In these primarily lacustrine units, paleosols with varying degrees of pedogenic carbonate development formed during the dry phases associated with low lake 
depth. Schaller et al. (2011a) used these soils to test both the magnitude and duration of the effects of the CAMP volcanism on atmospheric $\mathrm{pCO}_{2}$.

In the Hartford basin, the oldest strata are the fluvial and marginal lacustrine facies of the Triassic New Haven Formation, where pedogenic carbonate-bearing paleosols are abundant (Hubert, 1978). The first volcanic unit is the Talcott Basalt, followed by the Holyoke and Hampden basalts, interbedded with the cyclic lacustrine sequences of the Shuttle Meadow and East Berlin Formations and the Smith's Ferry and Park River members of the lower Portland Formation (Figs. 1 and 3). Interspersed throughout these lake sequences are more weakly developed paleosols, where periodic subaerial exposure of the primary sediments allowed soil-forming processes to operate on the lake margins (e.g., Tanner, 2003).

The predictive framework of Milankovitch cycle stratigraphy has been used to demonstrate that the flow units and interbedded sedimentary sequences of the Hartford basin are directly equivalent to those present in the Newark basin (Olsen, 1988; Whiteside et al., 2007) (Figs. 1 and 4). Therefore, the Shuttle Meadow Formation represents $\sim 260 \mathrm{kyr}$, and the East Berlin Formation $290 \mathrm{kyr}$. Recently, the magnetostratigraphy of the Hartford basin has extended the Newark timescale into the Early Jurassic (Kent and Olsen, 2008), through sampling of the largely lacustrine lower $2000 \mathrm{~m}$ of the thick post-extrusive Portland Formation, which is the primary focus of the current study.

\section{Estimating $\mathrm{pCO}_{2}$ from pedogenic carbonates}

Pedogenic carbonate nodules were collected from paleosols located stratigraphically above and below each of the CAMP flows in the Hartford basin from both cores and outcrop. Samples from New Haven Formation, distributed 500 and $1200 \mathrm{~m}$ below the Talcott Basalt, provided a pre-CAMP baseline. Since the mostly fluvial New Haven lacks cycle or magnetic stratigraphy, these samples are treated as a single relative background value for comparison to the Newark basin record. The samples situated $\sim 1200 \mathrm{~m}$ below the Talcott Basalt are from exposures dated using $\mathrm{U}-\mathrm{Pb}$ at $211 \pm 2.1 \mathrm{Ma}$ by Wang et al. (1998), and we estimate the sample at $500 \mathrm{~m}$ below the basalt to be $\sim 205 \mathrm{Ma}$. Samples from the lower Shuttle Meadow Formation are from a cored section near Berlin, CT (Silver Ridge Core B-1 (see Whiteside et al., 2011)) as well as from outcrop. The upper 75\% of the East Berlin Formation is well exposed but suitable paleosols are rare. The lower $600 \mathrm{~m}$ of the post-extrusive Portland Formation is covered in high resolution with significant overlap by a series of short geotechnical cores taken by the Army Corps of Engineers (ACE) during construction of the Park River flood diversion tunnel project (Kent and Olsen, 2008; Pienkowski and Steinen, 1995). Samples from exposures in the middle to upper Portland Formation were assembled using the stratigraphy of Kent and Olsen (2008), and our uppermost sample is from near the top of the mostly lacustrine part of the Portland Formation (see Table 1 for all sample and core location data).

Organic and inorganic carbon isotope measurements from these paleosols were input into the soil diffusion model of Cerling (1999):

$C_{a}=S(z) \frac{\delta_{s}-1.0044 \delta_{\phi}-4.4}{\delta_{a}-\delta_{s}}$

where $C_{a}$ is the concentration of atmospheric $\mathrm{CO}_{2}, S(z)$ is the concentration of $\mathrm{CO}_{2}$ at soil depths greater than $50 \mathrm{~cm}$ contributed by the respiration of soil organic matter, $\delta_{s}$ is the $\delta^{13} \mathrm{C}$ of soil $\mathrm{CO}_{2}, \delta_{\varphi}$ is the $\delta^{13} \mathrm{C}$ of soil-respired $\mathrm{CO}_{2}$, and $\delta_{a}$ is the $\delta^{13} \mathrm{C}$ of atmospheric $\mathrm{CO}_{2}$. All $\delta$ values are relative to Vienna PeeDee Belemnite (VPDB).

The carbon isotopic ratio of soil carbonate $\left(\delta_{c c}\right)$ is used as a proxy for $\delta_{s}$, which involves a temperature-dependent equilibrium fractionation between $\mathrm{CaCO}_{3}$ and $\mathrm{CO}_{2}$, described by:

$10^{3} \ln \alpha=11.709-0.116(\mathrm{~T})+2.16 \times 10^{-4}(\mathrm{~T})^{2}$
(Cerling, 1999) where $\alpha$ is the fractionation factor, and temperature ( $\mathrm{T}$, in ${ }^{\circ} \mathrm{C}$ ) is fixed at $25^{\circ} \mathrm{C}$, as appropriate for the tropical Newark basin. Because there is no carbon isotope fractionation due to respiration, $\delta_{\varphi}$ is related directly to the carbon isotopic ratio of soil organic matter $\left(\delta^{13} \mathrm{C}_{\mathrm{org}}\right)$. The carbon isotopic ratio of the atmosphere is calculated from the measured $\delta^{13} \mathrm{C}_{\mathrm{org}}$ by the following relationship (Arens et al., 2000):

$\delta_{a}=\left(\delta^{13} \mathrm{C}_{\mathrm{org}}+18.67\right) / 1.10$

which assumes consistent fractionation by photosynthesis. This builds carbon cycle perturbations directly into the model. The only adjustable parameter of the model is the concentration of $\mathrm{CO}_{2}$ in the soil derived from the respiration of organic matter $(S(z))$, which is a function of soil productivity. The paleosols sampled in this study were relatively productive argillic and vertic calcisols (Mack et al., 1993), with mean depth to the Bk horizon $\left(D_{s}\right)$ at $40 \pm 15 \mathrm{~cm}$ soil depth, which we use to estimate $S(z)$ by the following empirical relationship: $S(z)=66.7 \mathrm{D}_{\mathrm{s}}+588$ (Retallack, 2009). This results in a mean $S(z)$ of $\sim 3256$ with an SE of $\pm 893 \mathrm{ppm}$. Given the difficulty inherent in accurately estimating depth to the Bk horizon in individual paleosols from drill cores, and in accordance with the work of Breecker et al. $(2009,2010)$, we use an $S(z)$ value of $3000 \pm 1000 \mathrm{ppm}$ for all $\mathrm{pCO}_{2}$ estimates, which gives a final $\mathrm{pCO}_{2}$ range that is indistinguishable from the error that would result from systematic use of the empirical depth to carbonate relationship. Individual soil profiles were not decompacted (Retallack, 2009), and our $S(z)$ approximations are therefore conservatively low.

A combination of thin sections and polished slabs are used to identify primary micritic calcite from diagenetic material (Driese and Mora, 2002),with a sampling preference for small, isolated carbonate nodules that are generally in better isotopic equilibrium with the surrounding soil than larger nodules or calcretes (Schaller et al., 2011a). Great care was taken to avoid phreatic calcretes, and to sample only those displaying clear evidence of having formed in the vadose zone (Rasbury et al., 2006). Samples for organic carbon isotope analysis were taken from as close to the soil-surface as possible to avoid measuring recalcitrant organics unrelated to the active organic carbon pool during soil formation (Nadelhoffer and Fry, 1988), and several samples from each profile were homogenized to provide a more representative organic carbon value.

The $\delta^{13} \mathrm{C}$ value of pedogenic carbonate is known to decrease predictably with soil depth (Quade et al., 1989), and characterizing this trend makes it possible to differentiate between the relative influences of the atmospheric vs. soil-respired $\mathrm{CO}_{2}$ reservoirs. Therefore, multiple (at least 5) down profile isotopic measurements were made on each paleosol to identify an equilibrium $\delta_{c c}$ value with depth in the soil (Schaller et al., 2011a) (Fig. 2). Using the mean of these depth-controlled measurements ensures that the mixing between the atmospheric and soil-respired reservoirs is at equilibrium with respect to the diffusion model, removing significant uncertainty in the isotopic maturity of a given paleosol profile.

Chronostratigraphic placement follows the cycle and magnetic stratigraphy of Kent and Olsen (2008) and Olsen et al. (2005). In the Park River ACE core suite, this cyclostratigraphy provides direct stratigraphic age control to the level of orbital precession, and correlates unambiguously to the post-extrusive Boonton Formation of the Newark basin (Kent and Olsen, 2008; Olsen et al., 2005).

\section{Results}

The depth-equilibrated mean stable carbon isotopic composition of pedogenic carbonate $\left(\delta^{13} \mathrm{C}_{\mathrm{cc}}\right)$ from exposures 500 to $1200 \mathrm{~m}$ below the Talcott basalt in the New Haven Formation ranges from -7.7 to $-7.2 \%$ (relative to VPDB), which are 
Table 1

Samples from both outcrop and core from the Hartford basin. Formations in bold are CAMP basalt units.

\begin{tabular}{|c|c|c|c|c|c|c|c|c|c|}
\hline \multirow[t]{2}{*}{ Sample } & \multicolumn{2}{|c|}{ Core or outcrop } & \multirow[t]{2}{*}{ Formation } & \multirow{2}{*}{$\begin{array}{l}\text { Depth } \\
\text { - below/+above } \\
\text { Talcott Base } \\
(\mathrm{m})\end{array}$} & \multirow{2}{*}{$\begin{array}{l}\text { Age } \\
(\mathrm{Ma})^{\mathrm{a}}\end{array}$} & \multirow{2}{*}{$\begin{array}{l}\text { Down-profile } \\
\text { mean } \delta^{13} C_{\text {carb }} \\
(\% \text { PDB })^{b}\end{array}$} & \multirow{2}{*}{$\begin{array}{l}\delta^{13} \mathrm{C}_{\mathrm{OM}} \\
(\% \circ \mathrm{PDB})^{\mathrm{C}}\end{array}$} & \multicolumn{2}{|c|}{$\begin{array}{l}\text { Atmos. } \mathrm{pCO}_{2}(\mathrm{ppm}) \\
(\text { at } \mathrm{Sz}=3000 \pm 1000 \mathrm{ppm})\end{array}$} \\
\hline & Lat & Lon & & & & & & (at $\mathrm{Sz}$ & 00 ppm) \\
\hline HNHTH3-50 & 41.55649 & -72.91159 & New Haven & $-1200^{\mathrm{d}}$ & $211.9^{\mathrm{d}}$ & -7.4 & -26.2 & 1775 & \pm 592 \\
\hline HNHTH2-47 & 41.55723 & -72.91175 & New Haven & $-1200^{\mathrm{d}}$ & $211.9^{\mathrm{d}}$ & -7.7 & -26.4 & 1703 & \pm 568 \\
\hline HNH691B & 41.55956 & -72.90775 & New Haven & $-1175^{\mathrm{d}}$ & $211.9^{\mathrm{d}}$ & -7.2 & -26.8 & 2218 & \pm 739 \\
\hline HNH691C ${ }^{\mathrm{e}}$ & 41.55981 & -72.90845 & New Haven & $-1170^{\mathrm{d}}$ & $211.9^{\mathrm{d}}$ & -7.6 & -26.9 & 2064 & \pm 688 \\
\hline $\mathrm{HNHAAD}^{\mathrm{e}}$ & 41.39441 & -72.8872 & $\begin{array}{l}\text { New Haven } \\
\text { Talcott Basalt }\end{array}$ & $\begin{array}{r}-500^{d} \\
0\end{array}$ & $\begin{array}{l}\sim 205 \\
201.38\end{array}$ & -7.6 & -27.0 & 2065 & \pm 688 \\
\hline HSMSRB1-165 & 41.5850 & -72.7565 & Shuttle Meadow & 120 & 201.26 & -3.4 & -26.2 & 5186 & \pm 1773 \\
\hline HSMAAA $^{\mathrm{e}}$ & 40.67295 & -72.83597 & $\begin{array}{l}\text { Shuttle Meadow } \\
\text { Holyoke Basalt }\end{array}$ & $\begin{array}{l}200 \\
241\end{array}$ & 201.18 & -6.6 & -26.0 & 3074 & \pm 1025 \\
\hline HEBFD26T-82 & 41.758639 & -72.69509 & $\begin{array}{l}\text { East Berlin } \\
\text { Hampden Basalt }\end{array}$ & $\begin{array}{l}540 \\
550\end{array}$ & 200.84 & -6.3 & -26.2 & 2249 & \pm 746 \\
\hline HPFD24T-112 & 41.758101 & -72.693243 & Portland & 597 & 200.78 & -4.6 & -27.7 & 5473 & \pm 1824 \\
\hline HPFD24T-107 & 41.758101 & -72.693243 & Portland & 599 & 200.78 & -5.3 & -26.1 & 2980 & \pm 993 \\
\hline HPFD24T-92 & 41.758101 & -72.693243 & Portland & 603 & 200.77 & -4.9 & -26.2 & 3530 & \pm 1177 \\
\hline HPFD14T-82 & 41.758201 & -72.690903 & Portland & 605 & 200.77 & -3.0 & -25.2 & 4391 & \pm 1464 \\
\hline HPFD20T-165 & 41.757929 & -72.68815 & Portland & 631 & 200.75 & -3.8 & -25.2 & 4518 & \pm 1506 \\
\hline HPFD20T-99 & 41.757929 & -72.68815 & Portland & 651 & 200.73 & -3.6 & -24.9 & 3574 & \pm 1191 \\
\hline HPFD16T-206 & 41.757913 & -72.684209 & Portland & 671 & 200.71 & -7.5 & -27.8 & 2727 & \pm 909 \\
\hline HPFD16T-154 & 41.757913 & -72.684209 & Portland & 686 & 200.69 & -6.3 & -27.2 & 3019 & \pm 1006 \\
\hline HPFD16T-126 & 41.757913 & -72.684209 & Portland & 695 & 200.68 & -7.1 & -27.7 & 2811 & \pm 937 \\
\hline HPFD16T-48 & 41.757913 & -72.684209 & Portland & 718 & 200.66 & -4.8 & -26.0 & 3455 & \pm 1152 \\
\hline HPFD13T-165 & 41.757635 & -72.677278 & Portland & 726 & 200.65 & -6.0 & -26.7 & 2988 & \pm 996 \\
\hline HPFD22T-210 & 41.757761 & -72.680457 & Portland & 744 & 200.63 & -6.2 & -27.1 & 3072 & \pm 1024 \\
\hline HPFD12T-210 & 41.757841 & -72.675222 & Portland & 745 & 200.63 & -5.8 & -25.5 & 2317 & \pm 772 \\
\hline HPFD18T-138 & 41.758023 & -72.682255 & Portland & 746 & 200.63 & -4.9 & -25.9 & 3280 & \pm 1093 \\
\hline HPFD12T-32 & 41.757841 & -72.675222 & Portland & 799 & 200.58 & -6.9 & -26.6 & 2204 & \pm 735 \\
\hline HPFD19T-188 & 41.757686 & -72.672524 & Portland & 801 & 200.58 & -6.8 & -27.0 & 2545 & \pm 848 \\
\hline HPFD23T-80 & 41.757715 & -72.671683 & Portland & 847 & 200.53 & -3.3 & -25.5 & 4496 & \pm 1499 \\
\hline HPFD19T-32 & 41.757686 & -72.672524 & Portland & 848 & 200.53 & -4.6 & -26.6 & 4125 & \pm 1375 \\
\hline HPFD30T-175 & 41.757341 & -72.668001 & Portland & 913 & 200.46 & -3.1 & -25.7 & 5092 & \pm 1697 \\
\hline HPFD30T-86 & 41.757341 & -72.668001 & Portland & 940 & 200.44 & -5.9 & -26.6 & 2882 & \pm 961 \\
\hline HPFD29T-185 & 41.757496 & -72.664766 & Portland & 983 & 200.39 & -5.6 & -26.4 & 3003 & \pm 1001 \\
\hline HPFD29T-97 & 41.757496 & -72.664766 & Portland & 1010 & 200.37 & -7.3 & -25.5 & 1496 & \pm 499 \\
\hline HPFD7T-101 & 41.758055 & -72.664892 & Portland & 1025 & 200.35 & -6.9 & -26.4 & 2117 & \pm 706 \\
\hline HPFD27T-154 & 41.757519 & -72.663522 & Portland & 1043 & 200.33 & -5.7 & -27.3 & 2649 & \pm 883 \\
\hline HPFD27T-94 & 41.757519 & -72.663522 & Portland & 1062 & 200.31 & -6.2 & -26.6 & 2716 & \pm 905 \\
\hline $\mathrm{HPEL}^{\mathrm{e}}$ & 41.5712 & -72.6198 & Portland & 1143 & 200.23 & -7.7 & -26.0 & 1528 & \pm 509 \\
\hline $\mathrm{HPEJ}^{\mathrm{e}}$ & 41.5723 & -72.6163 & Portland & 1224 & 200.15 & -9.3 & -26.0 & 915 & \pm 305 \\
\hline HPJFA $^{\mathrm{e}}$ & 41.9747 & -72.6598 & Portland & 1582 & 199.79 & -9.5 & -25.8 & 785 & \pm 262 \\
\hline HPJPEG $^{\mathrm{e}}$ & 41.9903 & -72.5937 & Portland & 2379 & 198.99 & -7.7 & -26.6 & 1768 & \pm 589 \\
\hline
\end{tabular}

a Age based on cycle and magnetic stratigraphy tied to 201.38 absolute ages of first extrusive unit (Schoene et al., 2010).

b Analyzed on a Micromass Optima - dual inlet IRMS.

c Analyzed on a Eurovector EA connected to VG Isoprime IRMS.

d Depth estimate $\pm 200 \mathrm{~m}$ error, based on projection of the bedding dip. Age estimates from U/Pb date of $211.9 \pm 2.1 \mathrm{Ma}$ (Wang et al., 1998) on same/adjacent exposure.

e Samples from outcrop.

comparable to values from the Passaic Formation of the Newark basin (see Table 1). These values are very close to those of Suchecki et al. (1988) from the New Haven Formation, which help to establish a consistent average pre-eruptive background. Stratigraphically above the Talcott Basalt, in the lower Shuttle Meadow Formation, pedogenic carbonates have $\delta^{13} \mathrm{C}$ values of $-3.2 \%$, which decrease to $-6.6 \%$ o toward the top of the formation (Fig. 3). Comparable values of $-6.3 \%$ are found at the top of the East Berlin Formation, which sits stratigraphically above the Holyoke Basalt (the second flow unit). The $\delta^{13} \mathrm{C}$ of soil organic matter was between $-26.3 \%$ and $-26.0 \%$ in the Shuttle Meadow and upper East Berlin formations. These values are consistent with results from the Feltville and Towaco Formations of the Newark basin (Schaller et al., 2011a), and the high $\delta^{13} \mathrm{C}$ of pedogenic carbonate above the Talcott Basalt (equivalent of the Newark Orange Mountain Basalt) probably represents the increased influence of the atmospheric $\mathrm{CO}_{2}$ reservoir on pedogenic carbonate formed at depth.

Calculated $\mathrm{pCO}_{2}$ levels through the New Haven Formation are treated as a single value, averaging $1900 \pm 650 \mathrm{ppm}$. Those samples from exposures roughly $1200 \mathrm{~m}$ below the Talcott basalt have a U-Pb age of $211.9 \pm 2.1 \mathrm{Ma}$ (Table 1 ) (Wang et al., 1998), and calculated $\mathrm{pCO}_{2}$ values of $\sim 1800$ to $2200 \pm 700 \mathrm{ppm}$
(Table 1; all $\mathrm{pCO}_{2}$ estimates at $S(z)=3000 \pm 1000 \mathrm{ppm}$ ), which are comparable to the $\sim 2000 \pm 700 \mathrm{ppm}$ of Schaller et al. (2011a) from the pre-CAMP Passaic Formation (204 to 201.5 Ma) in the Newark basin. These samples from the lower New Haven indicate that a pre-eruptive Triassic $\mathrm{pCO}_{2}$ baseline may have persisted for at least $~ 10 \mathrm{Myr}$ before the initial CAMP eruptions, a significant extension of the available Newark record.

Just above the Talcott Basalt in the Shuttle Meadow Formation, $\mathrm{pCO}_{2}$ increases to $\sim 5000 \pm 1500 \mathrm{ppm}$ followed by a decrease to $\sim 3000 \pm 1000 \mathrm{ppm}$ just beneath the Holyoke Basalt. These $\mathrm{pCO}_{2}$ levels are comparable to those observed in the first posteruptive strata of the Feltville Formation in the Newark basin, at $\sim 4400 \pm 1400 \mathrm{ppm}$ directly on top of the Orange Mountain Basalt (Fig. 4). Atmospheric $\mathrm{pCO}_{2}$ at the top of the East Berlin Formation, just below the Hampden Basalt, is roughly $2200 \pm 750$ ppm, which is consistent with the $\sim 2000 \mathrm{ppm}$ background values found at the top of the Towaco Formation of the Newark basin (Fig. 4). Although the resolution of these few inter-CAMP points in the Hartford basin is sporadic, their consistency with the record from the Newark strata (Fig. 4) reinforces the independence of individual values and the global applicability of this approach. 


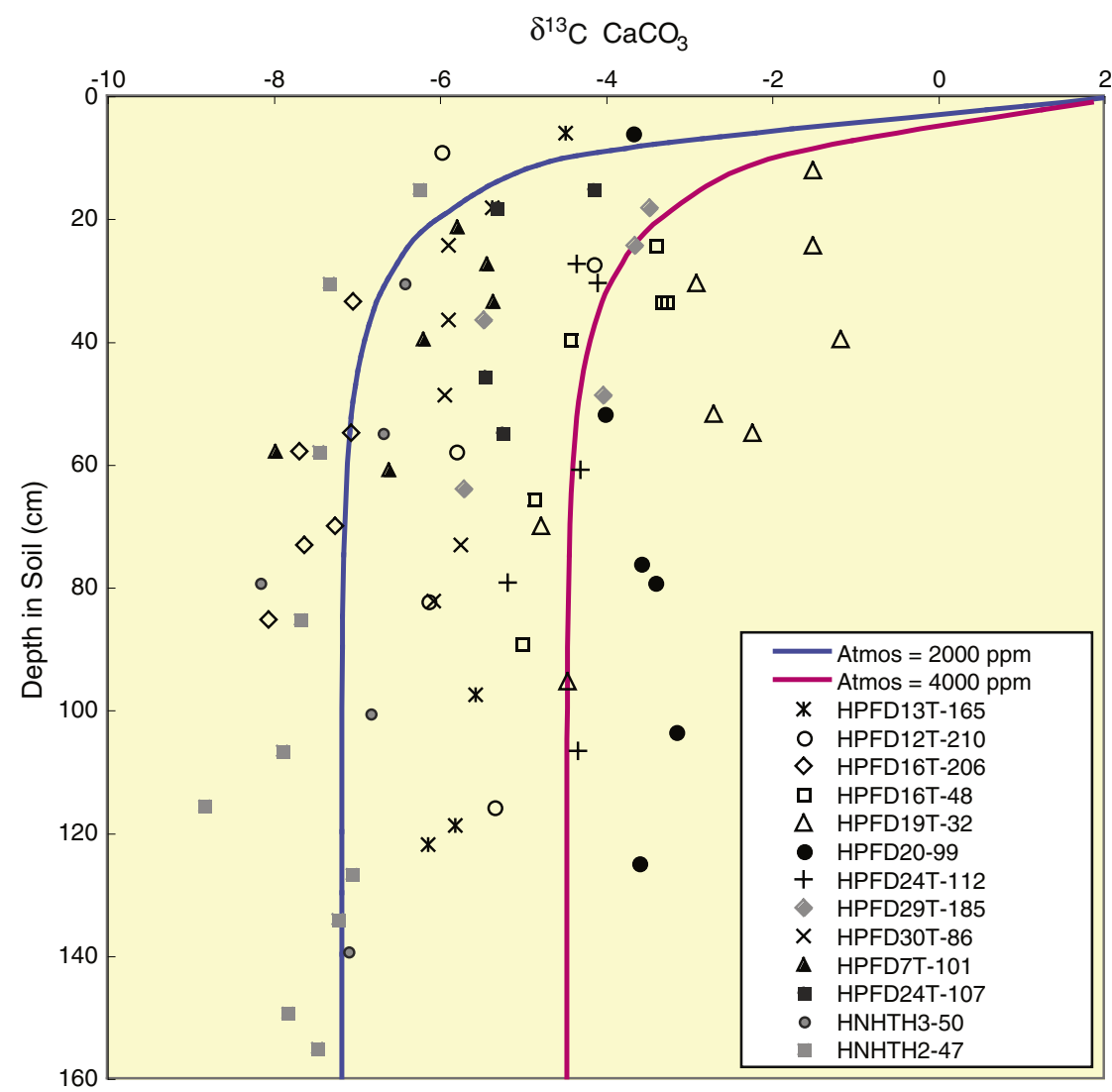

Fig. 2. Stable carbon isotopic composition of pedogenic carbonate $\left(\delta_{c c}\right)$ with estimated soil depth from representative paleosols in the Portland Formation (symbols encompass analytical error). Note that these shallowest nodules represent depths to the uppermost carbonate nodules, which should not be confused with depth to the Bk horizon (Retallack, 2009). Observed $\delta_{c c}$ is compared to the $\delta_{c c}$ values predicted by the diffusion model at atmospheric $\mathrm{CO}_{2}$ concentrations of $2000 \mathrm{ppm}$ (blue line) and $4000 \mathrm{ppm}$ (pink line) (after Quade et al., 1989). For this demonstration only, atmospheric $\delta^{13} \mathrm{CO}_{2}$ was set to $-6.5 \%$, soil $\delta^{13} \mathrm{C}_{\mathrm{org}}$ was set to -26.5 , with an exponential production function and characteristic depth of production at $15 \mathrm{~cm}$ (other parameters described in text). For all $\mathrm{pCO}_{2}$ estimates made in this study, the $\delta^{13} \mathrm{C}_{\mathrm{org}}$ was measured directly and used as a model input. Soil carbonate above $20 \mathrm{~cm}$ in the profile was rare; note that stabilization of measured $\delta_{c c}$ is commonly well below $50 \mathrm{~cm}$ soil depth. Only the mean of the equilibrium $\delta_{c c}$ values were used to calculate $\mathrm{pCO}_{2}$ in this study. (For interpretation of the references to color in this figure legend, the reader is referred to the web version of this article.)

In the post-extrusive Portland Formation, pedogenic carbonates have $\delta^{13} \mathrm{C}$ values of -3 to $-5 \%$ just above the Hampden Basalt, decreasing to $-7 \%$ about $200 \mathrm{~m}$ up section (Fig. 3). Around $240 \mathrm{~m}$ above the Hampden Basalt, the $\delta^{13} \mathrm{C}_{\mathrm{cc}}$ again increases to $-3.5 \%$, followed by a falloff through the rest of the sampled Portland Formation to a minimum of $-9.5 \%$ \% $2400 \mathrm{~m}$ (1.8 Myr) above the Hampden Basalt. The $\delta^{13} \mathrm{C}$ of soil organic matter $\left(\delta^{13} \mathrm{C}_{\mathrm{OM}}\right)$ also shows variability through the Portland Formation, ranging from $-24.9 \%$ 。 to $-27.8 \%$ 。 (Fig. 3). Similar to the Newark record, $\delta{ }^{13} \mathrm{C}_{\mathrm{OM}}$ decreases slightly just above the Hampden Basalt, followed by an immediate swing toward higher values. Overall, the lower Portland Formation exhibits 3\%。 variability in $\delta^{13} \mathrm{C}_{\mathrm{OM}}$ that stabilizes up section.

Calculated atmospheric $\mathrm{pCO}_{2}$ in the Portland Formation shows a few distinct trends. In soils formed directly on top of the Hampden Basalt, $\mathrm{pCO}_{2}$ levels are $\sim 5400 \pm 1500 \mathrm{ppm}$, with some fluctuation in the calculated $\mathrm{pCO}_{2}$ level before settling to $\sim 4300 \pm 1200 \mathrm{ppm}$ (Fig. 3). This apparent fluctuation, observed in a single core above the Hampden Basalt, is driven by the $\delta^{13} \mathrm{C}$ of soil organic matter, because the $\delta^{13} \mathrm{C}$ of pedogenic carbonate is relatively stable in the first $10 \mathrm{~m}$ above the basalt. Because these soils are relatively weakly developed and organic matter was rare, the few apparently lower $\mathrm{pCO}_{2}$ values are likely a product of ${ }^{13} \mathrm{C}$ enriched recalcitrant organic matter that is unrelated to the active decomposition pool during pedogenesis (Nadelhoffer and Fry, 1988). Aside from these few points, the majority of the calculated $\mathrm{pCO}_{2}$ changes in the Hartford basin appear to be driven by the $\delta^{13} \mathrm{C}$ of pedogenic carbonate.

Above the initial increase, atmospheric $\mathrm{pCO}_{2}$ gradually decreases to near background levels in the first $200 \mathrm{~m}$ of the post-extrusive
Portland Formation. At about $240 \mathrm{~m}$ above the Hampden Basalt, $\mathrm{pCO}_{2}$ again peaks to $\sim 4500 \pm 1200 \mathrm{ppm}$, which is captured laterally across 2 individual cores, followed by a steady decrease to below background levels through the rest of the $1700 \mathrm{~m}$ of sampled section (Fig. 3).

Because the Park River Member is equivalent to a part of the Boonton Formation of the Newark basin, the $\mathrm{pCO}_{2}$ values found in the Portland are expected to be consistent with the Boonton record, where an increase to $\sim 5000 \mathrm{ppm}$ is noted just above the Hook Mountain Basalt (Fig. 4), and where the next few samples some $350 \mathrm{~m}$ up section yield $\mathrm{pCO}_{2}$ levels of $\sim 3000-2500 \mathrm{ppm}$. These values from the upper Boonton Formation were previously thought to be anomalously high, but are in fact directly consistent with similar high concentrations following the $\mathrm{pCO}_{2}$ peak at $240 \mathrm{~m}$ in the Portland Formation. It appears that the full expression of the final observed $\mathrm{pCO}_{2}$ pulse of the Portland (the fourth of the Newark-Hartford section) was simply not captured by the low resolution record from the Boonton Formation due to lack of appropriate lithology, and yet the few points present in the upper Newark match their chronostratigraphic equivalents in the Hartford. The $\mathrm{pCO}_{2}$ estimates from the Portland Formation show excellent reproducibility across section between overlapping individual cores. Overall, the Hartford basin $\mathrm{pCO}_{2}$ record is tightly consistent with that of the Newark basin $(\sim 250 \mathrm{~km}$ to the south), despite independent age control used for correlation (error within a few precession cycles between basins) and our use of parameterized $S(z)$ values of $3000 \pm 1000 \mathrm{ppm}$, and temperatures fixed at $25{ }^{\circ} \mathrm{C}$ in the records generated from both basins (Figs. 4 and 6). 
HARTFORD BASIN
A litho-strat.
B $\delta^{13} \mathrm{C} \mathrm{CaCO}_{3}$
\%。 (PDB)
C $\delta^{13} \mathrm{Corg}$.
\%。 (PDB)
D $\mathrm{pCO}_{2}(\mathrm{ppm})$
$\begin{array}{llllllllll}-10 & -9 & -8 & -7 & -6 & -5 & -4 & -3 & -2 & -28\end{array}$
$\begin{array}{lll}-27 & -26 & -25\end{array}$
$10-1 S(z)=3000 \pm 1000 \mathrm{ppm}$
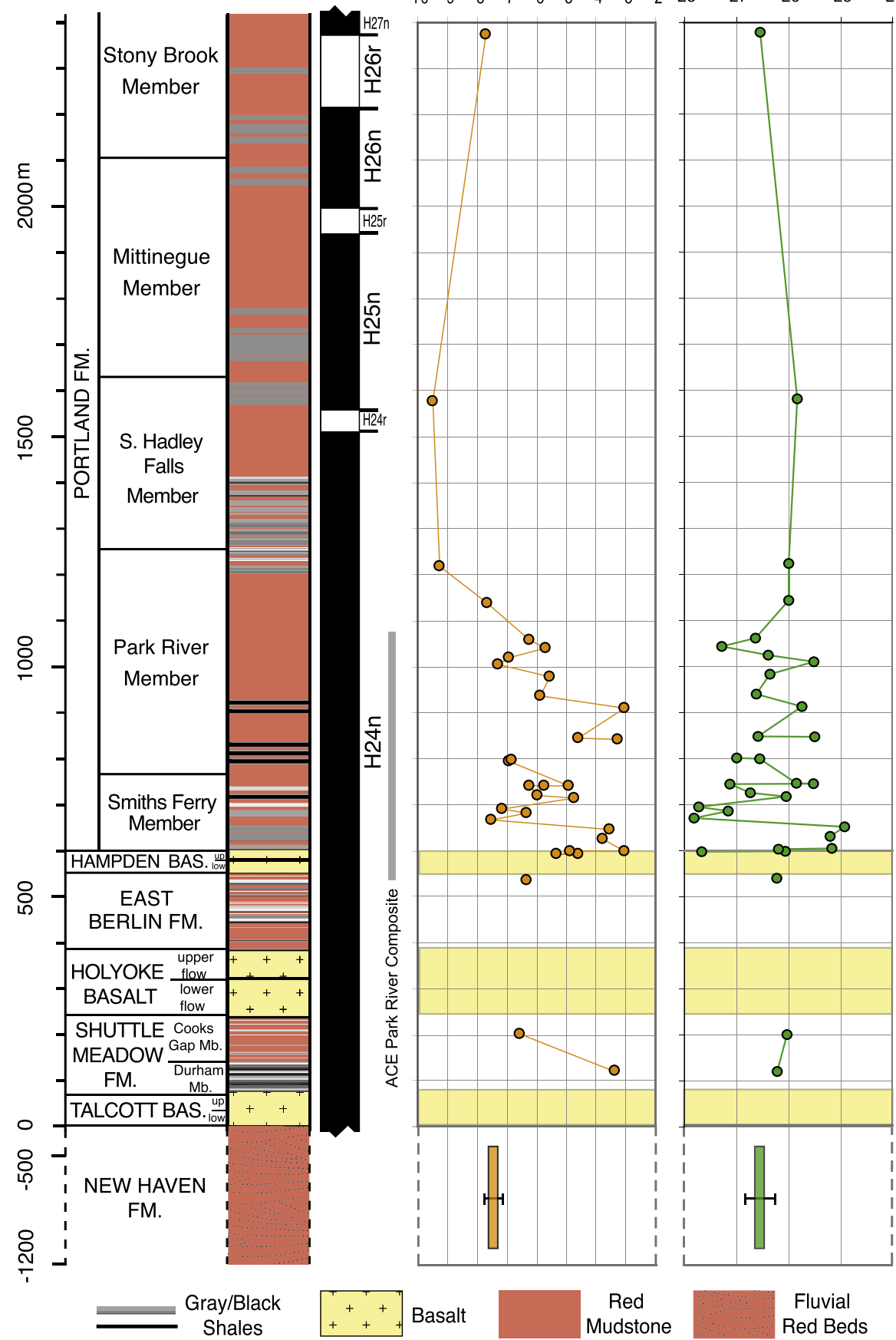

Fig. 3. A. Lithologic and polarity stratigraphy of the Hartford basin from Kent and Olsen (2008). B. Profile equilibrated mean $\delta^{13} \mathrm{C}$ values of pedogenic carbonate. C. $\delta^{13} \mathrm{C}$ of organic matter from as close to the paleosol surface as possible. D. Calculated $\mathrm{pCO}_{2}$ based on input variables in $\mathrm{B}$ and $\mathrm{C}$ at $25^{\circ} \mathrm{C}$. The concentration of respired $\mathrm{CO}_{2}$ in the soil $[S(z)]$ was estimated at $3000 \pm 1000 \mathrm{ppm}$, and the resulting range of $\mathrm{pCO}_{2}$ is indicated by the \pm error bars on each estimate. For $\mathrm{B}, \mathrm{C}$, and $\mathrm{D}$, only the mean \pm standard deviation of the 5 sample locations from the New Haven Formation is shown because of stratigraphic uncertainty; see Table 1 for depths below the Talcott Basalt.

\section{A fourth major pulse of volcanism?}

With one exception, each pulse of $\mathrm{CO}_{2}$ observed in the Newark and Hartford records is found only directly above a unit of CAMP lavas, and each observed $\mathrm{pCO}_{2}$ increase has accordingly been attributed to the volcanic activity responsible for the emplacement of the underlying extrusive unit (Schaller et al., 2011a). The observed increase in $\mathrm{pCO}_{2}$ $\sim 240 \mathrm{~m}$ from the base of the Portland Formation, or $\sim 240 \mathrm{kyr}$ after the extrusion of the Hampden Basalt, is of roughly the same size and duration as those in the Newark and Hartford record that are directly preceded by laterally extensive extrusive units (Fig. 5). Also, the $\delta^{13} \mathrm{C}$ of organic matter shows little indication of another (perhaps lighter) source of carbon feeding this $\mathrm{CO}_{2}$ pulse (e.g., Svensen et al., 2004). Therefore we attribute this fourth rise to a fourth episode of substantial and rapid volcanism, similar in magnitude to those episodes corresponding to the observed lava flow units in the Newark and Hartford basins. 


\section{HARTFORD BASIN}

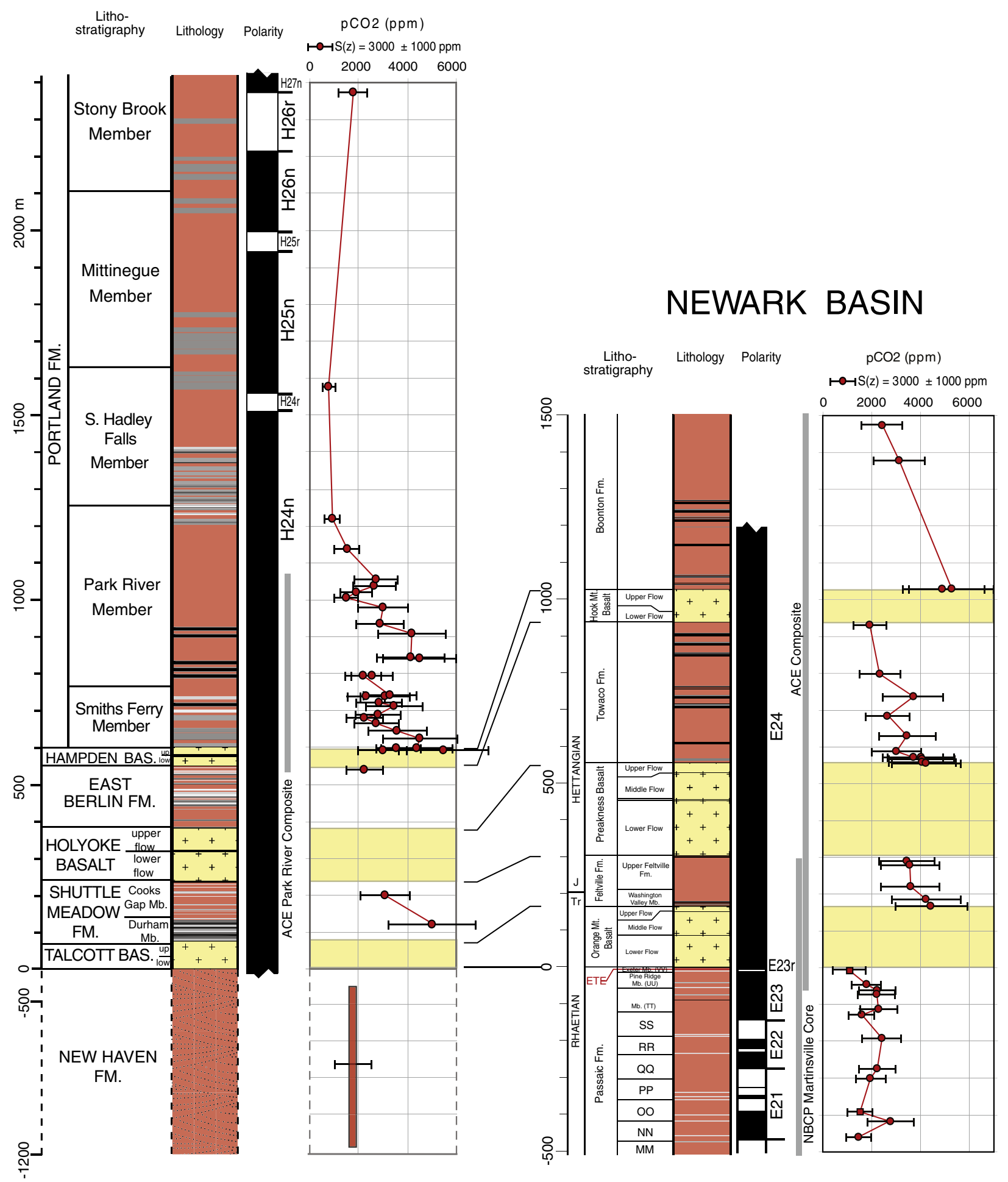

Fig. 4. Calculated $\mathrm{pCO}_{2}$ from the Hartford basin compared to the Newark basin $\mathrm{pCO}_{2}$ record of Schaller et al. (2011a). Error bars represent calculated pCO ${ }_{2}$ at soil respired $\mathrm{CO}_{2}$ concentrations $[S(z)]$ of $3000+1000$ ppm. The Army Corps of Engineers (ACE) suite of Park River cores is denoted by gray bar in the Hartford basin, covering the lower Portland Formation in high resolution. For comparison to the pre-CAMP background of Schaller et al. (2011a), samples from the New Haven Formation are shown as a mean of the pCO 2 estimates between $\sim 500 \mathrm{~m}$ and $\sim 1200 \mathrm{~m}$ below the Talcott Basalt (see Table 1), with an error corresponding to $S(z)$ values of $3000 \pm 1000$ ppm.

However, there is no solid evidence in Eastern North America for a fourth major pulse of CAMP activity (see Olsen et al., 2011 for review; Weems and Olsen, 1997). A thin unnamed basalt caps the Culpeper basin sequence about $\sim 1300 \mathrm{~m}$ above the Sanders Basalt. However, there is structural ambiguity (Lee and
Froelich, 1989), and the unnamed basalt may in fact be a faulted portion of the underlying Sanders Basalt (Weems and Olsen, 1997), making it an unlikely candidate for the volcanic episode that produced the fourth $\mathrm{pCO}_{2}$ increase observed in the Hartford basin. 


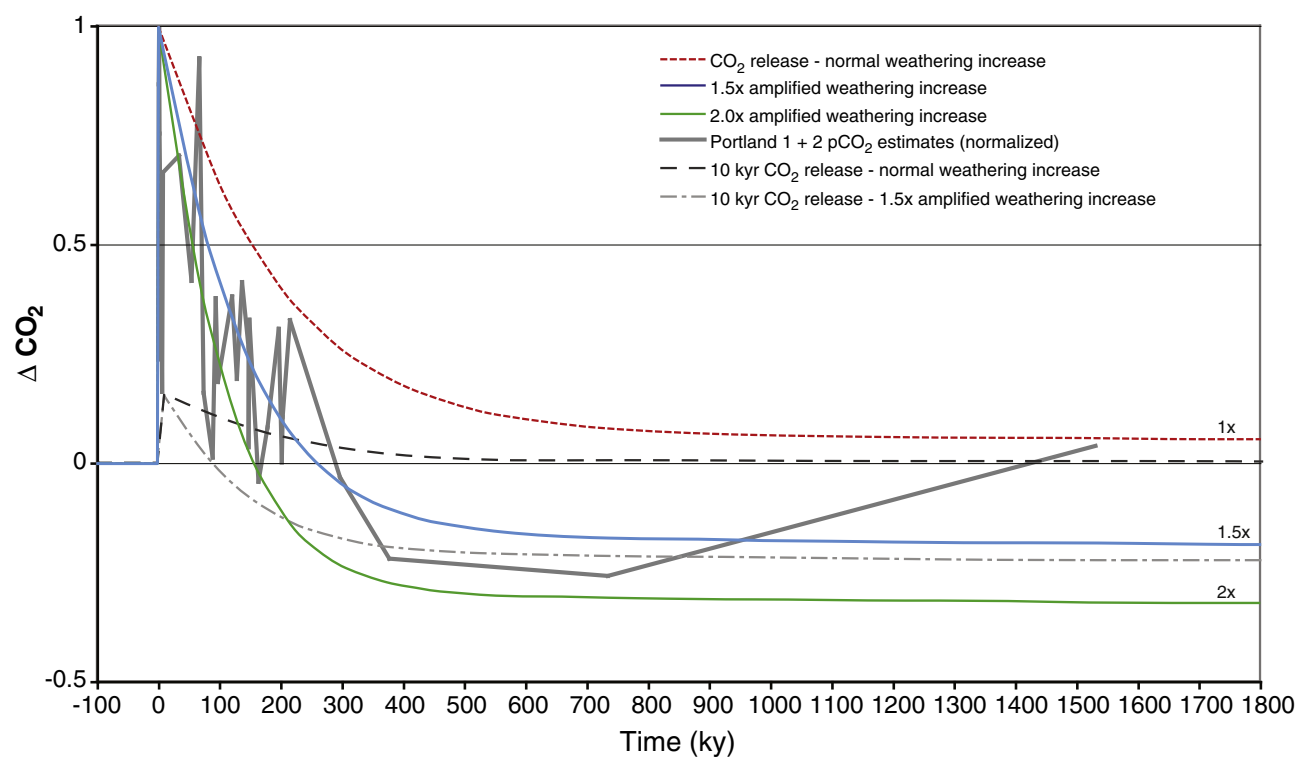

Fig. 5. The $\mathrm{pCO}_{2}$ record of the post-extrusive Portland Formation (at $S(z)=3000 \mathrm{ppm}$ ) (gray line), normalized to their respective increases above background, combined with one another, and scaled to an initial eruptive pulse at $\mathrm{t}=0$, for comparison to the results of geochemical modeling using a modified version of the COPSE model (Bergman et al., 2004). The model equilibrates the atmosphere and ocean on the 1000-year timescale. In the reference run (red dotted-line), the model achieves steady state for 100 kyr, at which point atmospheric $\mathrm{CO}_{2}$ was doubled over 1000 years (by adding $3.5 \times 10^{17} \mathrm{~mol}$ of $\mathrm{CO}_{2}$ ) to simulate the eruption of a single pulse of $\mathrm{CAMP}_{\mathrm{V}}$ volcanics and their $\mathrm{CO}_{2}$ release. The ensuing decrease in $\mathrm{pCO}_{2}$ is due to consumption by increased continental weathering rate resulting from the high $\mathrm{pCO}_{2}$ and resultant increased temperatures. In the test simulations, the ocean-atmosphere $\mathrm{CO}_{2}$ reservoir was again doubled in size, while the increased rate of silicate weathering was concordantly further amplified by1.5 (blue line) and 2 times (green line), in an attempt to simulate the effects of freshly erupted basalts on the continental weathering budget. A second set of test simulations shows the effect of the same $\mathrm{CO}_{2}$ pulse released over $10 \mathrm{kyr}$ without an amplification of the weathering increase (black dashed line), and with a $1.5 \times$ amplification (gray dot-dash line).The model was run for a total of $1.9 \mathrm{Myr}$. Linear correlation of each 1000 -year release simulation to the observed normalized Portland pCO ${ }_{2}$ estimates at $S(z)=3000$ ppm (using least-squares) gives $R^{2}=-0.03$ for the reference simulation, $R^{2}=0.62$ for the 1.5 time amplification of the weathering increase, and $R^{2}=0.46$ for the 2 time amplification. (For interpretation of the references to color in this figure legend, the reader is referred to the web version of this article.)

Similarly, four distinct flow units have been recognized in the corollary High Atlas region of Morocco, deemed the Lower, Intermediate and Upper Units, and the Recurrent Basalt, on the basis of major element geochemistry (Bertrand, 1991). Although there is debate regarding the detailed stratigraphic placement of the Lower Basalt (Deenen et al., 2010; Marzoli et al., 2004; Whiteside et al., 2007), the Recurrent is geochemically similar to Hook Mountain and Hampden Basalts (Deenen et al., 2010; Marzoli et al., 2011), leaving the volcanism responsible for the Recurrent a possible, but still unlikely tracer for the fourth $\mathrm{pCO}_{2}$ increase observed in the Hartford basin. The South American CAMP extrusive section remains largely unstudied stratigraphically, and it is unclear how these volcanics are related to the ENA section. Despite CAMP dikes, sills and rarer lava flows preserved over several million square kilometers of northern South America (see Marzoli et al., 1999 for review), it is at present impossible to determine the precise temporal or stratigraphic relationship of these volcanic units at the level necessary to isolate a single widespread eruptive event as the cause for the fourth $\mathrm{pCO}_{2}$ pulse observed in the Hartford basin. In addition, the age(s) of the Clubhouse Crossroads Basalt and their possible relationship to the voluminous seaward-dipping reflectors offshore is unclear (Olsen et al., 2003), and hence some of this igneous activity cannot be readily dismissed as a potential source for the fourth $\mathrm{pCO}_{2}$ pulse.

Most importantly, as evidenced by the fourth $\mathrm{pCO}_{2}$ peak in the Hartford basin, the CAMP-induced $\mathrm{pCO}_{2}$ increases should be identifiable in any section with the appropriate lithology and high sedimentation rate, regardless of the presence of CAMP lavas. Identifying these four $\mathrm{pCO}_{2}$ pulses in other basins is an essential step toward understanding the stratigraphy of the extrusive zone, and potentially adds a higher degree of precision to global correlation. In that light, the identification of a fourth apparent volcanogenic pulse in the Hartford basin allows us to revise the total duration of CAMP induced high $\mathrm{pCO}_{2}$ as observed in the ENA basins from $600 \pm 20 \mathrm{kyr}$ (Olsen et al., 2003; Whiteside et al., 2007), to $840 \pm 60 \mathrm{kyr}$, based on the amount of time present between the base of the Talcott Basalt and the last apparent pulse of $\mathrm{CO}_{2}$ in the Portland Formation using the chronostratigraphy of Kent and Olsen (2008).

\section{Weathering of the CAMP basalts}

A notable characteristic of the post-eruptive CAMP record is the striking decrease in atmospheric $\mathrm{pCO}_{2}$ within a few hundred thousand years of basalt emplacement (Fig. 6). In the Newark record $\mathrm{pCO}_{2}$ falls from an excess of $\sim 4000 \mathrm{ppm}$ to nearly background levels of $\sim 2000 \mathrm{ppm}$ within $\sim 300 \mathrm{kyr}$ of the extrusives. Similarly, in the post-extrusive Portland Formation of the Hartford basin, we observe a decrease over a comparable timescale (following both the Hampden Basalt and the fourth $\mathrm{pCO}_{2}$ increases discussed above). Unlike the others, $\mathrm{pCO}_{2}$ continues to decline following the final pulse in the Portland Formation, and ultimately levels off at concentrations below preeruptive background. We hypothesize that both the rapidity of the $\mathrm{pCO}_{2}$ decreases, and the fall in $\mathrm{pCO}_{2}$ to below background are due to the rapid consumption of $\mathrm{CO}_{2}$ by an overall increase in continental weathering, which is accelerated by the relatively rapid hydrolysis of the freshly erupted CAMP silicates themselves.

\subsection{Modeling the post-extrusive $\mathrm{pCO}_{2}$ decrease}

Here, we use a geochemical model to demonstrate that the rapid decrease in atmospheric $\mathrm{pCO}_{2}$ following the CAMP eruptions may indeed be due to basalt-induced amplification of the predicted increase in continental weathering. We use a modified version of the COPSE biogeochemical model (Bergman et al., 2004) in perturbation mode, which couples the carbon, oxygen, phosphorus and sulfur cycles, with explicit feedbacks between atmospheric $\mathrm{pCO}_{2}$ and temperature to the rate of continental silicate weathering.

In the case of the Orange Mountain Basalt in the Newark basin (the oldest flow unit), the duration of eruption is well constrained 


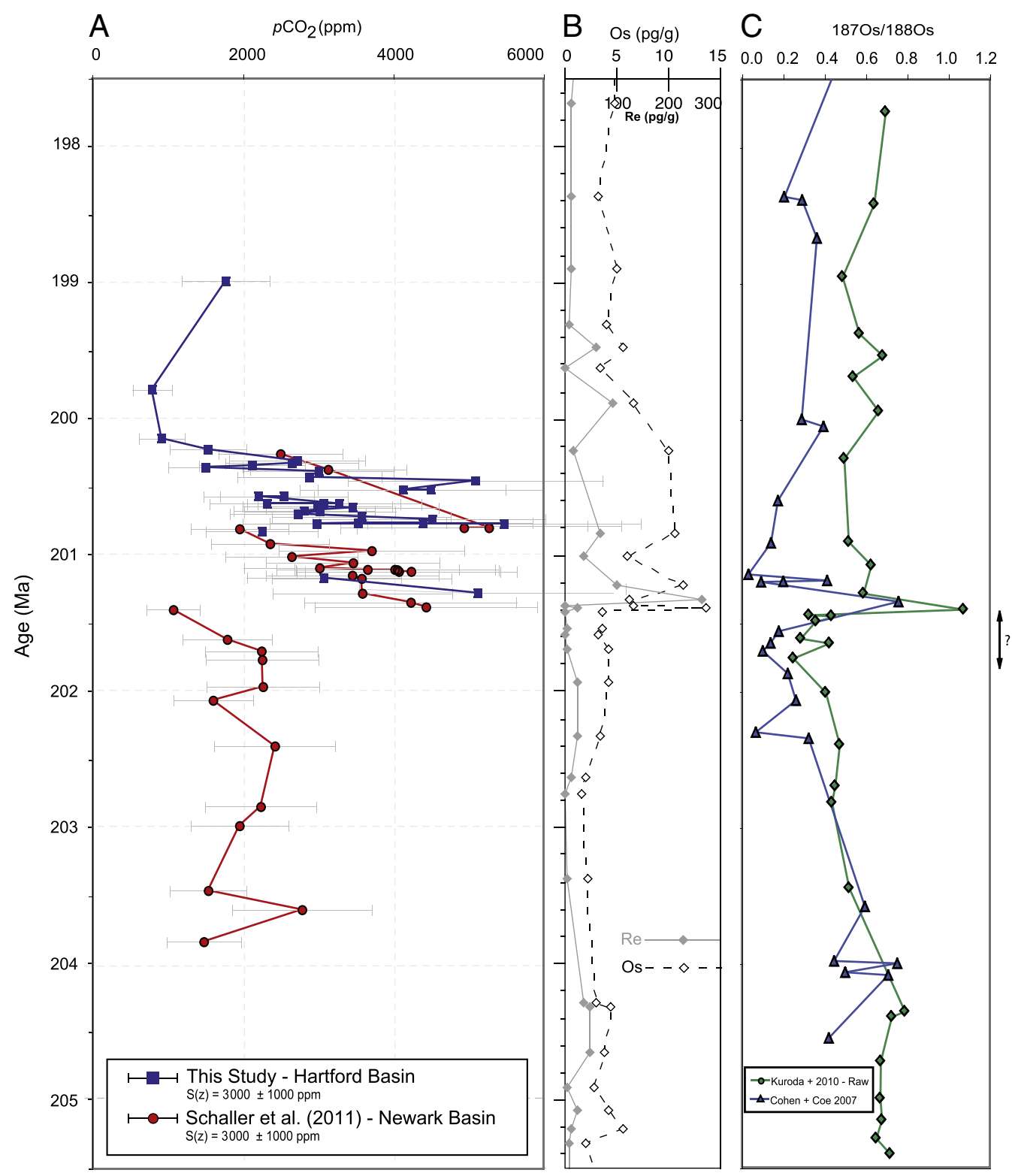

Fig. 6. A. Composite Newark and Hartford $\mathrm{pCO}_{2}$ record of this study. Newark data are from Schaller et al. (2011a). B. The [Os] and [Re] records from the Kurusu section in Japan, plotted using the accumulation rates of Kuroda (2010), with the record correlated using the peak in ${ }^{187} \mathrm{Os} /{ }^{188} \mathrm{Os}$ to the corresponding ${ }^{187} \mathrm{Os} /{ }^{188} \mathrm{Os}$ peak in the isotope record of Cohen and Coe (2007). (note difference in Re and Os scales). C. ${ }^{187} \mathrm{Os} /{ }^{188} \mathrm{Os}$ ratios from the Kurusu section in Japan (Kuroda et al., 2010) and the St. Audrey's Bay, U.K. (Cohen and Coe, 2007). Here we have used the peak in ${ }^{187} \mathrm{Os} /{ }^{188}$ Os in St. Audrey's Bay (Cohen and Coe, 2007) as a marker for a more appropriate correlation to the Kurusu section (contra Kuroda et al., 2010), which is afforded by the error in biostratigraphy and the residence time of Osmium in the oceans (Oxburgh, 2001). Placement offset noted by arrow.

to within a single precession cycle (Olsen et al., 2003; Whiteside et al., 2007), and a doubling of $\mathrm{pCO}_{2}$ over pre-eruptive background is observed directly on top of the uppermost lava flow of the Orange Mountain. Each volcanic episode shows roughly the same $\mathrm{pCO}_{2}$ response, with a similar durational constraint (with the exception of the Preakness and equivalent Holyoke basalts), and we are not aware of any data, geochemical or otherwise, that precludes an eruption time as short as 1000 years ( $1 \mathrm{kyr}$ ) for a single extrusive unit (e.g., see Schaller et al., 2011b). The absence of significant sedimentary strata or deep weathering profiles between individual lava flows of a single extrusive unit (e.g., within the Hampden Basalt) favors a short amount of time between lava flows, especially considering the high long-term sediment accumulation rates of $\sim 1$ meter per thousand years (Kent and Olsen, 2008). Therefore, we use a total eruptive duration of 1000 years for a single extrusive unit in our geochemical modeling, and for reference, show the results of a 10,000year (10 kyr) degassing scenario with an identical release.
The perturbation mode of the modified COPSE model starts from a $100 \mathrm{kyr}$ steady state where mid-ocean ridge degassing is balanced by silicate weathering as a function of $\mathrm{pCO}_{2}$ and temperature at initial conditions. The model couples the surface ocean-atmospheric C-reservoir on a 1000-yr time-scale, and runs at $100-y r$ timesteps. In our simulations, we roughly double the size of the atmospheric fraction of the coupled ocean-atmosphere reservoir by adding $3.5 \times 10^{17} \mathrm{~mol}$ of $\mathrm{CO}_{2}$ over 1000 years to reproduce the observed doubling of atmospheric $\mathrm{CO}_{2}$ immediately following the CAMP eruptions, which is roughly one third of the total $\mathrm{CO}_{2}$ potentially degassed from a total estimated CAMP basalt volume of the $\sim 3 \times 10^{6} \mathrm{~km}^{3}$ (Schaller et al., 2011a; Schaller et al., 2011b; Self et al., 2006). We run the model for a total of $1900 \mathrm{kyr}$, and in the reference run simply watch the weathering response of the system to this doubling over the ensuing $1800 \mathrm{kyr}$ of model time. In an attempt to simulate the effect of an increase in the weathering potential of the 
continental surface, we further amplify the increased rate of continental silicate weathering at the time of $\mathrm{CO}_{2}$ perturbation by 1.5 and 2 times the normal effect.

\subsection{Model results}

The reference simulation shows the prescribed doubling of $\mathrm{pCO}_{2}$ after the $100 \mathrm{kyr}$ steady state, followed by an asymptotic drawdown to relatively stable $\mathrm{pCO}_{2}$ levels that are slightly higher than the preperturbation steady-state by $600 \mathrm{kyr}$ after the release (Fig. 5, dashed red line). This suggests that the silicate weathering system is capable of removing the majority of a doubling perturbation within $\sim 600 \mathrm{kyr}$, but the increase in weathering due to the rapid transient increase in $\mathrm{pCO}_{2}$ (and greenhouse temperature) is not enough to lower $\mathrm{pCO}_{2}$ levels below pre-eruptive background, as observed in the postCAMP record from the Hartford basin.

A 1.5 times amplification of the increased weathering rate at the time of $\mathrm{CO}_{2}$ perturbation returns the system to pre-eruptive background $\mathrm{pCO}_{2}$ levels by $\sim 270 \mathrm{kyr}$, and eventually falls to about $20 \%$ below steady-state background (Fig. 5, blue line). A 2 times amplification returns $\mathrm{pCO}_{2}$ to background levels by $180 \mathrm{kyr}$ postperturbation, eventually falling to well below pre-eruptive background $(\sim 30 \%)$ for the remaining $1500 \mathrm{kyr}$ of simulation (Fig. 5, green line). The $10 \mathrm{kyr}$ reference simulations (Fig. 5, black and gray dashed lines) both show roughly $12 \%$ of the initial atmospheric $\mathrm{pCO}_{2}$ response as the $1 \mathrm{kyr}$ runs using the same $3.5 \times 10^{17} \mathrm{~mol}$ release.

The $\mathrm{pCO}_{2}$ decreases to below pre-eruptive background in the Portland Formation cannot be a function of a normal increase in weathering due to $\mathrm{CO}_{2}$ perturbation (as in the reference run), indicating that some amplification of the weathering increase is required. However, a 2 times amplification (above the background increase due to increased temperature and $\mathrm{CO}_{2}$ alone) reduces $\mathrm{pCO}_{2}$ to levels further below background than observed in the Portland Formation. Therefore, we suggest that a ca. 1.5 times amplification of the silicate weathering increase adequately describes the two post-eruptive decreases observed in the Portland. This demonstrates that the highly weatherable basalts erupted into the equatorial humid belt must be partially responsible for the rapidity of the $\mathrm{pCO}_{2}$ drawdown, and the decrease to below pre-eruptive background, by amplifying the increased in global weathering rates by perhaps 1.5 times. It should be noted that the timing and duration of the $\mathrm{pCO}_{2}$ fluctuations are well-constrained parameters of the Newark-Hartford $\mathrm{pCO}_{2}$ record, due to the precision of the astrochronology on these strata (Kent and Olsen, 1999, 2008; Olsen and Kent, 1996; Olsen et al., 1996a; Olsen et al., 2003). Therefore, the rate of drawdown is entirely dependent on calculated $\mathrm{pCO}_{2}$ values and not an artifact of poor age control.

Since the difference between the test simulations and the reference run is essentially a function of basalt area available for hydrolysis, we can estimate the proportion of basalt necessary to further amplify the rate of continental weathering by a factor of 1.5. Assuming that a continental flood basalt may weather at a rate 10 times that of granitic continental crust (Dessert et al., 2003; Gaillardet et al., 1999), increasing the weathering potential of the total continental surface by a factor of 1.5 may be achieved by erupting enough basalt to cover $\sim 1 / 18$ th the continental area, or $\sim 8.3 \times 10^{6} \mathrm{~km}^{2}$ (assuming total land area of roughly $1.5 \times 10^{8} \mathrm{~km}^{2}$ ). This figure is comparable to estimates of the CAMP eruptive area at $1.12 \times 10^{7} \mathrm{~km}^{2}$ (McHone et al., 2003). Additionally, it appears that the rate of post-extrusive drawdown is faster in the later part of the composite NewarkHartford record than earlier in the eruptive history (see Fig. 6). This may be due to the continuously increasing amount of basalt available to participate in weathering reactions with increasing time from the initial eruptions.

\subsection{Comparison to the Deccan}

Modeling experiments similar to those performed here have been used to evaluate the effects of the Deccan LIP (Caldeira and Rampino, 1990; Dessert et al., 2001), which lacks direct estimates of $\mathrm{pCO}_{2}$. In their most aggressive eruptive scenario, Caldeira and Rampino (1990) release $2.0 \times 10^{17} \mathrm{~mol} \mathrm{CO} \mathrm{CO}_{2}$ over an eruptive duration of $100 \mathrm{kyr}$, resulting in a meager $\sim 65 \mathrm{ppm}$ increase in $\mathrm{pCO}_{2}$. This $\mathrm{CO}_{2}$ release is close to that used in the present study, but Caldeira and Rampino (1990) assume a much longer eruptive duration, which results in a highly attenuated effect (e.g., see Schaller et al., 2011b). They find that equilibrium is reestablished $\sim 1.5 \mathrm{Myr}$ after the eruption of the Deccan Traps; however, their model incorporates only a modest increase in continental weathering at the time of perturbation, and does not include an amplification to account for the Deccan basalts, so $\mathrm{pCO}_{2}$ does not fall below pre-eruptive background.

In contrast, Dessert et al. (2001) use a much larger single $\mathrm{CO}_{2}$ release $\left(1.6 \times 10^{18} \mathrm{~mol} \mathrm{CO} 2\right.$ over $\left.100 \mathrm{kyr}\right)$, which amounts to a $\sim 1800 \mathrm{ppm}$ increase, or a little over a doubling of atmospheric $\mathrm{pCO}_{2}$, which is similar to the increase observed in response to the CAMP. More importantly, the presence of the Deccan basalts themselves resulted in the return of $\mathrm{pCO}_{2}$ to pre-eruptive levels by $1.2 \mathrm{Myr}$ after perturbation, followed by a continued decline to equilibrium at levels $20 \%$ lower than pre-eruptive concentrations. They conclude that the increased continental weathering potential afforded by the presence of the Deccan lava pile was essential in rapidly reducing atmospheric $\mathrm{pCO}_{2}$ below steady state background.

The results of Dessert et al. (2001) for the Deccan are consistent with the findings of this study of the CAMP, but have a significantly longer relaxation time: $\mathrm{pCO}_{2}$ does not return to pre-eruptive background until $\sim 1.2 \mathrm{Myr}$ after perturbation in the Dessert et al. (2001) simulation, compared to the $\sim 300 \mathrm{kyr}$ return observed in the CAMP record. Several factors probably account for this difference. First, the Dessert et al. (2001) simulation releases a large quantity of $\mathrm{CO}_{2}$ over a relatively long eruptive period ( $100 \mathrm{kyr})$ to induce a $\sim$ doubling of atmospheric $\mathrm{pCO}_{2}$, which may take a significantly longer amount of time to remove completely. A much smaller total amount of $\mathrm{CO}_{2} \mathrm{can}$ be released over a much shorter duration (e.g., $3.5 \times 10^{17}$ released over 1000 years, as in our simulations) and result in roughly the same doubling of atmospheric $\mathrm{pCO}_{2}$. Thus, on timescales greater than 1000 years, or the nominal overturning time of the oceans (Broecker and Peng, 1982), nearly 10 times more $\mathrm{CO}_{2}$ is needed to produce the same atmospheric effect, which may require additional $\mathrm{CO}_{2}$ sources (e.g., see Schaller et al., 2011b; Rampino and Caldeira, 2011). This is apparent in our simulations (Fig. 5) where $3.5 \times 10^{17} \mathrm{~mol}$ of $\mathrm{CO}_{2}$ are released on both $10 \mathrm{kyr}$ and $1 \mathrm{kyr}$ timescales; the $10 \mathrm{kyr}$ release resulted in $\sim 12 \%$ of the initial atmospheric $\mathrm{pCO}_{2}$ increase as that of the $1 \mathrm{kyr}$ scenario. Secondly, a more minor contributing factor is that the weatherable area of the Deccan Traps was estimated to be $\sim 2 \times 10^{6} \mathrm{~km}^{2}$, which is considerably smaller than the total estimated area of the CAMP eruptions $\left(\sim 1.12 \times 10^{7} \mathrm{~km}^{2}\right)$, and hence has a more limited potential to absorb $\mathrm{CO}_{2}$. Thirdly, CAMP straddled the paleoequator where weathering may have been more intense than that of the Deccan, which was emplaced in the tropical arid belt $\left(\sim 26^{\circ} \mathrm{S}\right.$ latitude) although it was subject to more intense weathering much later when India drifted into the equatorial humid belt (Kent and Muttoni, 2008).

Parenthetically, the rate of $\mathrm{CO}_{2}$ release will also affect the degree of ocean acidification. Hautmann (2004) hypothesized that drastic increases in $\mathrm{pCO}_{2}$ around the Triassic-Jurassic transition may have caused rapid ocean acidification, and hence undersaturation of seawater with respect to $\mathrm{CaCO}_{3}$, based on a global carbonate gap in the stratigraphic record. Berner and Beerling (2007) use a geochemical model to test this hypothesis, and conclude that a minimum release of $8.3 \times 10^{17} \mathrm{~mol} \mathrm{CO}(10,000 \mathrm{GtC})$ in less than $100 \mathrm{kyr}$ is necessary to induce wide-spread $\mathrm{CaCO}_{3}$ dissolution. However, a degassing scenario where $\sim 3 \times 10^{17} \mathrm{~mol} \mathrm{CO}_{2}$ is released in $\sim 1 \mathrm{kyr}$, as we suggest 
is recorded in the Newark Group where four such pulses of roughly $\sim 3.5 \times 10^{17} \mathrm{~mol} \mathrm{CO}_{2}$ each are observed, is probably sufficient to produce a $\mathrm{CaCO}_{3}$ undersaturated ocean.

\subsection{Other indicators of increased $\mathrm{pCO}_{2}$ and global weathering rates}

Our $\mathrm{pCO}_{2}$ estimates are corroborated by other independent reconstructions at lower resolutions. In particular, stomatal densities have shown a doubling to tripling of $\mathrm{pCO}_{2}$ across the ETE, followed by a $600 \mathrm{kyr}$ plateau at elevated concentrations (McElwain et al., 1999). Despite showing the same relative change as the Newark Group paleosol estimates, the absolute values of the stomata-based approximations are appreciably lower and show little variability within the CAMP interval. This apparent lack of resolution within the CAMP interval is probably because both the stomatal index and density proxies have an asymptotic response to increasing $\mathrm{pCO}_{2}$ (Beerling and Royer, 2002b), and therefore become insensitive at extremely high concentrations, showing little further change as saturation is approached. The offset between the paleosol estimates and the leaf stomata record may also be due to calibration issues, where the stomatal density proxy may underestimate $\mathrm{pCO}_{2}$ (Beerling and Royer, 2002a).

Pedogenic carbonate $\mathrm{pCO}_{2}$ reconstructions from the western U.S. (Cleveland et al., 2008) are comparable to the pre-eruptive background levels found in the New Haven and Passaic formations of this study. The Ghost Ranch and Montoya sections of Cleveland et al. (2008) lack CAMP volcanics and instead rely on a chronology derived from fluvial sequence stratigraphy (Cleveland et al., 2007). Without evidence that these sections extend into the Early Jurassic, long distance-correlation to the Newark record at the stage level overlaps the Ghost Ranch and Montoya $\mathrm{pCO}_{2}$ estimates with our pre-CAMP baseline. Although their estimates are highly variable, they are not inconsistent with pre-CAMP data from the Passaic (Schaller et al., 2011a) or New Haven Formations presented here $(\sim 2000 \pm 700 \mathrm{ppm})$. The variability in the Cleveland et al. (2008) data can be attributed to their lack of multiple down-profile isotope measurements, such that equilibration with soil $\mathrm{CO}_{2}$ is unknown, lack of individual organic measurements from each soil, and also to their use of temperatures estimated from the $\delta^{18} \mathrm{O}$ of pedogenic calcite, which has not been rigorously calibrated for use in the paleorecord (Dworkin et al., 2005).

Several marine sections spanning the Late Triassic to Early Jurassic show evidence for a marked increase in basalt weathering product. Most notably, substantial fluctuations in the ${ }^{187} \mathrm{Os} /{ }^{188} \mathrm{Os}$ of seawater between 203 and $197 \mathrm{Ma}$ are found in marine sections from St. Audrey's Bay, UK (Cohen and Coe, 2007), and the Kurusu section from Japan (Kuroda et al., 2010), an effect which is attributed to increased flux of unradiogenic ${ }^{188} \mathrm{Os}$ from the weathering of the CAMP (Cohen and Coe, 2007) (Fig. 6). To explain this relative increase in ${ }^{188} \mathrm{Os}$, Cohen and Coe (2007) conclude that perhaps as much as $50 \%$ of the estimated $3 \times 10^{6} \mathrm{~km}^{3}$ of basalt could have been removed in a 3 Myr window following the eruptions, a rate which is close to the current weathering rate of ocean island basalts (Gaillardet et al., 1999). This interpretation is also supported by 2- to 3-fold increases in Os and Re concentrations in the Kurusu section in Japan (Kuroda et al., 2010) that we correlate to the St. Audrey's Bay record via the ${ }^{187} \mathrm{Os} /{ }^{188} \mathrm{Os}$ peak in both, within the error allowed by the biostratigraphy (Ward et al., 2004). The relatively low ${ }^{187} \mathrm{Os} /{ }^{188} \mathrm{Os}$ ratio that occurs just after the initial CAMP eruptions indicates that unradiogenic ${ }^{188}$ Os was a significant proportion of the weathering flux, and the subsequent slow ${ }^{187} \mathrm{Os} /{ }^{188} \mathrm{Os}$ increase suggests that the proportion of unradiogenic component progressively decreased as the highly weatherable CAMP silicate was consumed. This scenario is consistent with our uppermost $\mathrm{pCO}_{2}$ estimate from the Portland formation, $1.5 \mathrm{Myr}$ after the last $\mathrm{pCO}_{2}$ increase, which suggests the return of atmospheric $\mathrm{pCO}_{2}$ to equilibrium levels following consumption of the CAMP basalts (Fig. 5). However, our scenario leaves the decrease in ${ }^{187} \mathrm{Os} /{ }^{188} \mathrm{Os}$ leading up to the initial CAMP eruptions unexplained.

\section{Summary and conclusion}

This paper presents evidence for the short and long-term effects of the CAMP volcanism on Early Jurassic $\mathrm{pCO}_{2}$ from strata in the Hartford basin of Eastern North America. We use the pedogenic carbonate paleobarometer (Cerling, 1999) to confirm the findings of Schaller et al. (2011a) in the corollary Newark basin, and to test the million-year scale effect of the CAMP eruptions.

We find that the Hartford basin $\mathrm{pCO}_{2}$ record is consistent with observations from the Newark basin, where a $\mathrm{pCO}_{2}$ maximum is identified just after each volcanic episode (to levels around $\sim 4500 \pm 1200 \mathrm{ppm}$ ). The significantly longer postextrusive Portland Formation of the Hartford basin shows evidence of a fourth pulse of $\mathrm{CO}_{2}$ (to $4500 \pm 1200 \mathrm{ppm}$ ) about $240 \mathrm{kyr}$ after the last lava recorded in the Eastern North American section. We contend that this increase in $\mathrm{CO}_{2}$ is volcanic in origin and may be attributed to a fourth pulse of widespread magmatism not represented by lavas in the ENA section. Using the fourth Newark Group pulse of $\mathrm{CO}_{2}$, found $240 \mathrm{kyr}$ after the Hampden Basalt, we revise the estimated CAMP duration as observed in the Eastern North American section to $840 \pm 60 \mathrm{kyr}$.

The Portland Formation record also shows a rapid post-eruptive decrease in $\mathrm{pCO}_{2}$ that reaches pre-eruptive background concentrations of $\sim 2000 \pm 700$ ppm by $\sim 250$ to $300 \mathrm{kyr}$, consistent with observations from the Newark basin. Furthermore, the longer Portland Formation exhibits a long-term decrease in $\mathrm{pCO}_{2}$ over the subsequent 1.5 Myr following the final eruptive episodes, to levels below the preCAMP background. We use a geochemical model based on the COPSE code to demonstrate that the rapidity of the decreases, and the fall to concentrations below background can be accounted for by a 1.5 times amplification of the continental silicate weathering response due to the presence of the CAMP basalts themselves. If basalt has 10 times the reactivity of continental crust, such an amplification would require $\sim 8.3 \times 10^{6} \mathrm{~km}^{2}$ of basalt to be erupted, comparable to estimates for the areal extent of the CAMP at $1.12 \times 10^{7} \mathrm{~km}^{2}$ (McHone et al., 2003). This finding is generally corroborated by other modeling efforts showing a similar response of the carbon system to the emplacement of the Deccan Traps with $1.6 \times 10^{18} \mathrm{~mol} \mathrm{CO}_{2}$ released over $100 \mathrm{kyr}$ (Dessert et al., 2001). However, our result departs in that we achieve a more rapid response of the carbon system by releasing far less $\mathrm{CO}_{2}\left(3.5 \times 10^{17} \mathrm{~mol}\right)$ over an eruption time of 1000 years for any one of the CAMP extrusive units. A longer eruption time therefore would require significantly more $\mathrm{CO}_{2}$ to be released to achieve the same effect.

Together, these results indicate that continental flood basalts may result in an extreme short-term perturbation of the carbon system, followed by a long-term net-drawdown in $\mathrm{pCO}_{2}$ to below preeruptive levels, implying that LIPs may have an overall net-cooling effect on climate through the connection between $\mathrm{pCO}_{2}$ and temperature.

\section{Acknowledgments}

We are particularly grateful to Jay Quade for his helpful discussion, Linda Godfrey for her technical lab assistance, Randy Steinen and Margaret Thomas for access to the Park River drainage project geotechnical cores, Noam Bergman for providing COPSE code, Roy Schlische for reviewing an early draft of this manuscript, and the two anonymous reviewers for their helpful critique. This research was supported by 2009 GSA and SEPM Graduate Research Awards (MFS), and an NSF grant EAR 0958867 (JDW and DVK). LamontDoherty Earth Observatory Contribution \#0000. 


\section{References}

Arens, N.C., Jahren, A.H., Amundson, R., 2000. Can C3 plants faithfully record the carbon isotopic composition of atmospheric carbon dioxide? Paleobiology 26 (1), 137-164

Beerling, D.J., Royer, D.L., 2002a. Fossil plants as indicators of the phanerozoic global carbon cycle. Ann. Rev. Earth Planet. Sci. 30, 527-556.

Beerling, D.J., Royer, D.L., 2002b. Reading a $\mathrm{CO}_{2}$ signal from fossil stomata. New Phytol. 153 (3), 387-397.

Bergman, N.M., Lenton, T.M., Watson, A.J., 2004. COPSE: a new model of biogeochemical cycling over Phanerozoic time. Am. J. Sci. 304 (5), 397-437.

Berner, R.A., Beerling, D.J., 2007. Volcanic degassing necessary to produce a $\mathrm{CaCO}_{3}$ undersaturated ocean at the Triassic-Jurassic boundary. Palaeogeogr. Palaeoclimatol. Palaeoecol. 244 (1-4), 368-373.

Bertrand, H., 1991. The Mesozoic tholeiitic provinces of northwest Africa: a volcanotectonic record of the early opening of central Atlantic, magmatism in extensional structural settings. In: Kampunzu, A.B., Lubala, R.T. (Eds.), The Phanerozoic African Plate. Springer, Berlin, pp. 147-188.

Breecker, D.O., Sharp, Z.D., McFadden, L.D., 2009. Seasonal bias in the formation and stable isotopic composition of pedogenic carbonate in modem soils from central New Mexico, USA Geol. Soc. Am. Bull. 121 (3-4), 630-640.

Breecker, D.O., Sharp, Z.D., McFadden, L.D., 576-580, 2010. Atmospheric CO2 concentrations during ancient greenhouse climates were similar to those predicted for A.D. 2100. Proc. Natl. Acad. Sci. 107 (2), 576-580.

Broecker, W.S., Peng, T.H., 1982. Tracers in the Sea. Eldigio Press Lamont Doherty Geological Observatory. $690 \mathrm{pp}$

Caldeira, K., Rampino, M.R., 1990. Carbon-dioxide emissions from Deccan volcanism and a K/T boundary greenhouse-effect. Geophys. Res. Lett. 17 (9), 1299-1302.

Cerling, T.E., 1999. In: Thiry, M., Simon-Coincon, R. (Eds.), Stable carbon isotopes in paleosol carbonates. : Palaeoweathering Palaesurfaces and other Related Continental Deposits, Volume 27. Special Publications of the International Association of Sedimentologists, Oxford, pp. 43-60.

Cleveland, D.M., Atchley, S.C., Nordt, L.C., 2007. Continental sequence stratigraphy of the Upper Triassic (Norian-Rhaetian) Chinle strata, northern New Mexico, USA allocyclic and autocyclic origins of paleosol-bearing alluvial successions. J. Sediment. Res. 77 (11-12), 909-924.

Cleveland, D.M., Nordt, L.C., Dworkin, S.I., Atchley, S.C., 2008. Pedogenic carbonate isotopes as evidence for extreme climatic events preceding the Triassic-Jurassic boundary: implications for the biotic crisis? GSA Bull. 120 (11/12), 1408-1415.

Coffin, M.F., Eldholm, O., 1993. Scratching the surface: estimating dimensions of large igneous provinces. Geology 21 (6), 515-518.

Cohen, A.S., Coe, A.L., 2007. The impact of the Central Atlantic Magmatic Province on climate and on the Sr- and Os-isotope evolution of seawater. Palaeogeogr. Palaeoclimatol. Palaeoecol. 244 (1-4), 374-390.

Courtillot, V.E., Renne, P.R., 2003. On the ages of flood basalt events. C.R. Geosci. 335 (1), 113-140.

Deenen, M.H.L., Ruhl, M., Bonis, N.R., Krijgsman, W., Kuerschner, W.M., Reitsma, M., van Bergen, M.J., 2010. A new chronology for the end-Triassic mass extinction. Earth Planet. Sci. Lett. 291 (1-4), 113-125.

Dessert, C., Dupre, B., Francois, L.M., Schott, J., Gaillardet, J., Chakrapani, G., Bajpai, S. 2001. Erosion of Deccan Traps determined by river geochemistry: impact on the global climate and the Sr-87/Sr-86 ratio of seawater. Earth Planet. Sci. Lett. 188 (3-4), 459-474

Dessert, C., Dupre, B., Gaillardet, J., Francois, L.M., Allegre, C.J., 2003. Basalt weathering laws and the impact of basalt weathering on the global carbon cycle. Chem. Geol. $202(3-4), 257-273$

Driese, S.G., Mora, C.I., 2002. Paleopedology and stabel-isotope goechemistry of late Triassic (Carnian-Norian) paleosols, Durham Sub-Basin, North Carlina, USA: implications for paleoclimate and plaeoatmospheric $\mathrm{pCO}_{2}$. In: Renaut, R.A., Ashley, G.M. (Eds.), Volume SEPM Special Publication, 73, pp. 207-218.

Dworkin, S.I., Nordt, L., Atchley, S., 2005. Determining terrestrial paleotemperature using the oxygen isotopic composition of pedogenic carbonate. Earth Planet. Sci. Lett. 237 (1-2), 56-68.

Gaillardet, J., Dupre, B., Louvat, P., Allegre, C.J., 1999. Global silicate weathering and $\mathrm{CO}_{2}$ consumption rates deduced from the chemistry of large rivers. Chem. Geol. 159 (1-4), 3-30.

Hames, W.E., Renne, P.R., Ruppel, C., 2000. New evidence for geologically instantaneous emplacement of earliest Jurassic Central Atlantic Magmatic Province basalts on the North American margin. Geology 28 (9), 859-862.

Hautmann, M., 2004. Effect of end-Triassic $\mathrm{CO}_{2}$ maximum on carbonate sedimentation and marine mass extinction. Facies 50 (2), 257-261.

Hubert, 1978. Paleosol caliche in the New Haven Arkose, Nweark Group, Connecticut Palaeogeogr. Palaeoclimatol. Palaeoecol. 24, 151-168.

Jourdan, F., Marzoli, A., Bertrand, H., Cirilli, S., Tanner, L.H., Kontak, D.J., McHone, G. Renne, P.R., Bellieni, G., 2009. 40Ar/39Ar ages of CAMP in North America: implications for the Triassic-Jurassic boundary and the 40K decay constant bias. Lithos $110(1-4), 167-180$

Kent, D.V., Muttoni, G., 2008. Equatorial convergence of India and early Cenozoic climate trends. Proc. Natl. Acad. Sci. U. S. A. 105 (42), 16065-16070.

Kent, D.V., Olsen, P.E., 1999. Astronomically tuned geomagnetic polarity timescale for the Late Triassic. J. Geophys. Res. Solid Earth 104 (B6), 12831-12841.

Kent, D.V., Olsen, P.E., 2008. Early Jurassic magnetostratigraphy and paleolatitudes from the Hartford continental rift basin (eastern North America): testing for polarity bias and abrupt polar wander in association with the Central Atlantic Magmatic Province. J. Geophys. Res. Solid Earth 113 (B6).

Kent, D.V., Olsen, P.E., Witte, W.K., 1995. Late Triassic-earliest Jurassic geomagnetic polarity sequence and paleolatitudes from drill cores in the Newark rift basin, eastern North America. J. Geophys. Res. 100, 14965-14998.
Knight, K.B., Nomade, S., Renne, P.R., Marzoli, A., Bertrand, H., Youbi, N., 2004. The Central Atlantic Magmatic Province at the Triassic-Jurassic boundary: paleomagnetic and Ar-40/Ar-39 evidence from Morocco for brief, episodic volcanism. Earth Planet. Sci. Lett. 228 (1-2), 143-160.

Kuroda, J., Hori, R.S., Suzuki, K., Grocke, D.R., Ohkouchi, N., 2010. Marine osmium isotope record across the Triassic-Jurassic boundary from a Pacific pelagic site. Geology 38 (12), 1095-1098.

Lee, K.Y., Froelich, A.J., 1989. Triassic-Jurassic stratigraphy of the Cuulpeper and Barboursville basins, Virginia and Maryland. U.S. Geol. Surv. Prof. Pap. 1472, 52.

Mack, G.H., James, W.C., Monger, H.C., 1993. Classification of paleosols. Geol. Soc. Am. Bull. 105 (2), 129-136.

Marzoli, A., Renne, P.R., Piccirillo, E.M., Ernesto, M., Bellieni, G., De Min, A., 1999. Extensive 200-million-year-old continental flood basalts of the Central Atlantic Magmatic Province. Science 284 (5414), 616-618.

Marzoli, A., Bertrand, H., Knight, K.B., Cirilli, S., Buratti, N., Verati, C., Nomade, S Renne, P.R., Youbi, N., Martini, R., Allenbach, K., Neuwerth, R., Rapaille, C., Zaninetti, L., Bellieni, G., 2004. Synchrony of the Central Atlantic Magmatic Province and the Triassic-Jurassic boundary climatic and biotic crisis. Geology 32 (11) 973-976.

Marzoli, A., Jourdan, F., Puffer, J.H., Cuppone, T., Tanner, L.H., Weems, R.E., Bertrand, H. Cirilli, S., Bellieni, G., De Min, A., 2011. Timing and duration of the Central Atlantic Magmatic Province in the Newark and Culpeper basins, eastern U.S.A. Lithos 122 (3-4), 175-188.

McElwain, J.C., Beerling, D.J., Woodward, F.I., 1999. Fossil plants and global warming at the Triassic-Jurassic boundary. Science 285 (5432), 1386-1390.

McHone, J.G., 2000. Non-plume magmatism and tectonics during the opening of the centralAtlanticOcean. Tectonophysics 316, 287-296.

McHone, J.G., et al., 2003. Volatile emissions from the Central Atlantic Magmatic Province basalts: mass assumptions and environmental consequences. In: Hames, W. (Ed.), The Central Atlantic Magmatic Province: insights from fragments of Pangea. : Volume Geophysical Monograph, 136. American Geophysical Union, Washington DC

Nadelhoffer, K.F., Fry, B., 1988. Controls on natural N-15 and C-13 abundances in forest soil organic-matter. Soil Sci. Soc. Am. J. 52 (6), 1633-1640.

Nomade, S., Knight, K.B., Beutel, E., Renne, P.R., Verati, C., Feraud, G., Marzoli, A., Youbi, N., Bertrand, H., 2007. Chronology of the Central Atlantic Magmatic Province: implications for the Central Atlantic rifting processes and the Triassic-Jurassic biotic crisis. Palaeogeogr. Palaeoclimatol. Palaeoecol. 244 (1-4), 326-344.

Olsen, P.E., 1986. A 40-million year lake record of early Mesozoic orbital climatic forcing. Science 234, 842-848.

Olsen, P.E., 1988. Continuity of strata in the Newark and Hartford Basins of the Newark Supergroup. U.S. Geol. Surv. Bull. 1776, 6-18.

Olsen, P.E., 1997. Stratigraphic record of the early Mesozoic breakup of Pangea in the Laurasia-Gondwana rift system. Ann. Rev. Earth Planet. Sci. 25, 337-401.

Olsen, P.E., Kent, D.V., 1996. Milankovitch climate forcing in the tropics of Pangaea during the Late Triassic. Palaeogeogr. Palaeoclimatol. Palaeoecol. 122 (1-4), 1-26.

Olsen, P.E., Kent, D.V., 1999. Long-period Milankovitch cycles from the Late Triassic and Early Jurassic of eastern North America and their implications for the calibration of the Early Mesozoic time-scale and the long-term behaviour of the planets. Philos. Trans. R. Soc. Lond. A 357 (1757), 1761-1786.

Olsen, P.E., Kent, D.V., Cornet, B., Witte, W.K., Schlische, R.W., 1996a. High-resolution stratigraphy of the Newark rift basin (early Mesozoic, eastern North America). Geol. Soc. Am. Bull. 108 (1), 40-77.

Olsen, P.E., Schlische, R.W., Fedosh, M.S., 1996b. 580 ky duration of the early jurassic flood basalt event in eastern North America estimated using Milankovitch cyclostratigraphy. In: Morales, M. (Ed.), The Continental Jurassic: Flagstaff, Museum of Northern Arizona Bulletin, 60, pp. 11-22.

Olsen, P.E., Kent, D.V., Et-Touhami, M., Puffer, J., 2003. Cyclo-, magneto-, and biostratigraphic constraints on the duration of the CAMP event and its relationship to the Triassic-Jurassic boundary. In: Hames, et al. (Ed.), The Central Atlantic Magmatic Province: Insights from Fragments of Pangea: Volume Geophysical Monograph, 136, pp. 7-32. Washington DC.

Olsen, P.E., Whiteside, J.H., LeTourneau, P.M., Huber, P., 2005. Jurassic cyclostratigraphy and paleontology of the Hartford Basin. In: Skinner, B.J., Philpotts, A.R. (Eds.), 97th New England Intercollegiate Geological Conference. Conn., Department of Geology and Geophysics, Yale University, New Haven, p. A4-1-A4-51.

Olsen, P.E., Kent, D.V., Whiteside, J.H., 2011. Implications of the Newark Supergroupbased astrochronology and geomagnetic polarity time scale (Newark-APTS) for the tempo and mode of the early diversification of the Dinosauria. Earth Environ. Sci. Trans. R. Soc. Edinburgh 101, 1-33.

Oxburgh, R., 2001. Residence time of osmium in the oceans. Geochem. Geophys. Geosyst. 2 (6)

Pienkowski, A., Steinen, R.P., 1995. Perennial lake cycles in the lower Portland Formation, Hartford, CT. Geol. Soc. Am. 27, 74 Abstracts with Programs.

Quade, J., Cerling, T.E., Bowman, J.R., 1989. Systematic variations in the carbon and oxygen isotopic composition of pedogenic carbonate along elevation transects in the southern Great Basin, United States. Geol. Soc. Am. Bull. 101 (4), 464-475.

Rampino, M.R., Caldeira, K., 2011. Comment on "Atmospheric $\mathrm{pCO}_{2}$ Perturbations Associated with the Central Atlantic Magmatic Province". Science 334 (6056), 594.

Rasbury, E.T., Gierlowski-Kordesch, E.H., Cole, J.M., Sookdeo, C., Spataro, G., Nienstedt, J., 2006. Calcite cement stratigraphy of a nonpedogenic calcrete in the Triassic New Haven Arkose (Newark Supergroup). In: Alonso-Zarza, A.M., Tanner, L.H. (Eds.), Volume Special Paper, 416. GSA, pp. 203-221.

Retallack, G.J., 2009. Refining a pedogenic-carbonate CO2 paleobarometer to quantify a middle Miocene greenhouse spike. Palaeogeogr. Palaeoclimatol. Palaeoecol. 281 (1-2), 57-65. 
Schaller, M.F., Wright, J.D., Kent, D.V., 2011a. Atmospheric $\mathrm{pCO}_{2}$ perturbations associated with the Central Atlantic Magmatic Province. Science 331 (6023), 1404-1409.

Schaller, M. F., Wright, J. D., Kent, D. V., 2011b. Response to Comment on “Atmospheric pCO2 Perturbations Associated with the Central Atlantic Magmatic Province": Science, v. 334, no. 6056, p. 594.

Schoene, B., Guex, J., Bartolini, A., Schaltegger, U., Blackburn, T.J., 2010. Correlating the end-Triassic mass extinction and flood basalt volcanism at the $100 \mathrm{ka}$ level. Geology 38 (5), 387-390.

Self, S., Widdowson, M., Thordarson, T., Jay, A.E., 2006. Volatile fluxes during flood basalt eruptions and potential effects on the global environment: a Deccan perspective. Earth Planet. Sci. Lett. $248(1-2), 518-532$.

Self, S., Blake, S., Sharma, K., Widdowson, M., Sephton, S., 2008. Sulfur and chlorine in late cretaceous Deccan magmas and eruptive gas release. Science 319 (5870), 1654-1657.

Smoot, J.P., 1991. Sedimentary Facies and Depositional-environments of Early Mesozoic Newark Supergroup Basins, Eastern North-America1991. Elsevier Science Bv, pp. 369-423.

Suchecki, R.K., Hubert, J.F., Dewet, C.C.B., 1988. Isotopic imprint of climate and hydrogeochemistry on terrestrial strata of the Triassic Jurassic Hartford and Fundy rift basins. J. Sediment. Petrol. 58 (5), 801-811.

Svensen, H., Planke, S., Malthe-Sorenssen, A., Jamtveit, B., Myklebust, R., Eidem, T.R., Rey, S.S., 2004. Release of methane from a volcanic basin as a mechanism for initial Eocene global warming. Nature 429 (6991), 542-545.

Tanner, L.H., 2003. Pedogenic record of paleoclimate and basin evolution in the Triassic Jurassic Fundy rift basin, Eastern Canada. In: Tourneau, P.M.L., Olsen, P.E. (Eds.) The Great Rift Valleys of Pangea in Eastern North America. Columbia University Press, New York.
Van Houten, F.B., 1962. Cyclic sedimentation and the origin of analcime-rich upper Triassic Lockatong Formation, west-central New Jersey and adjacent Pennsylvania. Am. J. Sci. 260, 561-576.

Verati, C., Rapaille, C., FĖraud, G., Marzoli, A., Bertrand, H., Youbi, N., 2007. 40Ar/39Ar ages and duration of the Central Atlantic Magmatic Province volcanism in Morocco and Portugal and its relation to the Triassic-Jurassic boundary. Palaeogeogr. Palaeoclimatol. Palaeoecol. 244 (1-4), 308-325.

Wang, Z.S., Rasbury, E.T., Hanson, G.N., Meyers, W.J., 1998. Using the U-Pb system of calcretes to date the time of sedimentation of elastic sedimentary rocks. Geochim. Cosmochim. Acta 62 (16), 2823-2835.

Ward, P.D., Garrison, G.H., Haggart, J.W., Kring, D.A., Beattie, M.J., 2004. Isotopic evidence bearing on Late Triassic extinction events, Queen Charlotte Islands, British Columbia, and implications for the duration and cause of the Triassic/Jurassic mass extinction. Earth Planet. Sci. Lett. 224 (3-4), 589-600.

Weems, R.E., Olsen, P.E., 1997. Synthesis and revision of groups within the Newark Supergroup, eastern North America. Geol. Soc. Am. Bull. 109 (2), 195-209.

Whiteside, J.H., Olsen, P.E., Kent, D.V., Fowell, S.J., Et-Touhami, M., 2007. Synchrony between the Central Atlantic Magmatic Province and the Triassic-Jurassic massextinction event? Palaeogeogr. Palaeoclimatol. Palaeoecol. 244 (1-4), 345-367.

Whiteside, J.H., Olsen, P.E., Eglinton, T.I., Cornet, B., McDonald, N.G., Huber, P., 2011. Pangean great lake paleoecology on the cusp of the end-Triassic extinction. Palaeogeogr. Palaeoclimatol. Palaeoecol. 301 (1-4), 1-17.

Wignall, P.B., 2001. Large igneous provinces and mass extinctions. Earth Sci. Rev. 53 (1-2), 1-33. 